\title{
Multifamily Housing Rehabilitation Process Improvements
}

Marshall L. Sweet, Abby Francisco, and Sydney G. Roberts Partnership for Home Innovation

March 2016 


\section{NOTICE}

This report was prepared as an account of work sponsored by an agency of the United States government. Neither the United States government nor any agency thereof, nor any of their employees, subcontractors, or affiliated partners makes any warranty, express or implied, or assumes any legal liability or responsibility for the accuracy, completeness, or usefulness of any information, apparatus, product, or process disclosed, or represents that its use would not infringe privately owned rights. Reference herein to any specific commercial product, process, or service by trade name, trademark, manufacturer, or otherwise does not necessarily constitute or imply its endorsement, recommendation, or favoring by the United States government or any agency thereof. The views and opinions of authors expressed herein do not necessarily state or reflect those of the United States government or any agency thereof.

Available electronically at SciTech Connect http:/www.osti.gov/scitech

Available for a processing fee to U.S. Department of Energy and its contractors, in paper, from:

U.S. Department of Energy

Office of Scientific and Technical Information

P.O. Box 62

Oak Ridge, TN 37831-0062

OSTI http://www.osti.gov

Phone: 865.576.8401

Fax: 865.576.5728

Email: reports@osti.gov

Available for sale to the public, in paper, from:

U.S. Department of Commerce

National Technical Information Service

5301 Shawnee Road

Alexandria, VA 22312

NTIS http://www.ntis.gov

Phone: 800.553 .6847 or 703.605 .6000

Fax: 703.605.6900

Email: orders@ntis.gov 


\title{
Multifamily Housing Rehabilitation Process Improvements
}

\author{
Prepared for: \\ The National Renewable Energy Laboratory \\ On behalf of the U.S. Department of Energy's Building America Program \\ Office of Energy Efficiency and Renewable Energy \\ 15013 Denver West Parkway \\ Golden, CO 80401 \\ NREL Contract No. DE-AC36-08GO28308 \\ Prepared by: \\ Marshall L. Sweet, Abby Francisco, and Sydney G. Roberts \\ Partnership for Home Innovation \\ 400 Prince George's Boulevard \\ Upper Marlboro, MD 20774 \\ NREL Technical Monitor: Stacey Rothgeb \\ Prepared under Subcontract No. KNDJ-0-40335-05
}

March 2016 
The work presented in this report does not represent performance of any product relative to regulated minimum efficiency requirements.

The laboratory and/or field sites used for this work are not certified rating test facilities. The conditions and methods under which products were characterized for this work differ from standard rating conditions, as described.

Because the methods and conditions differ, the reported results are not comparable to rated product performance and should only be used to estimate performance under the measured conditions. 


\section{Contents}

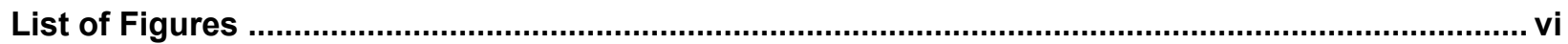

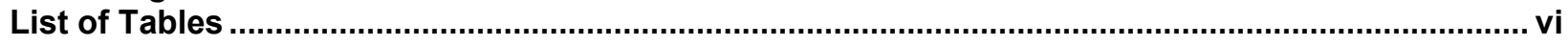

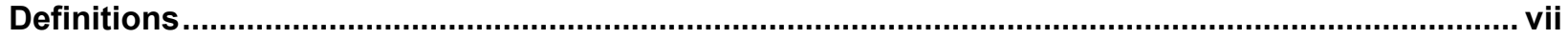

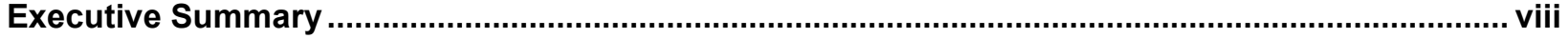

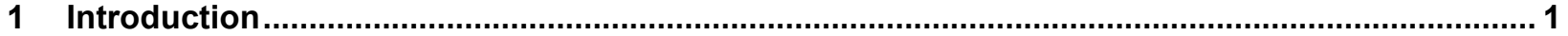

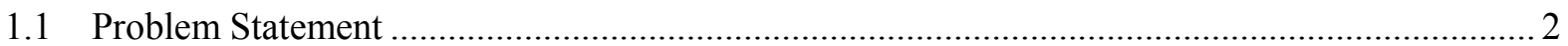

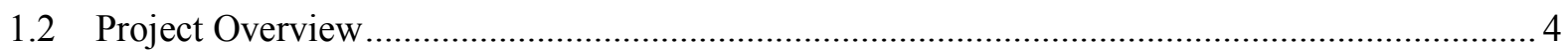

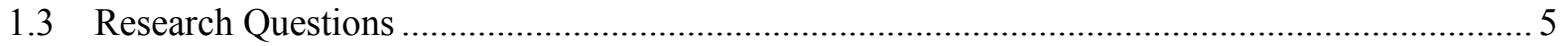

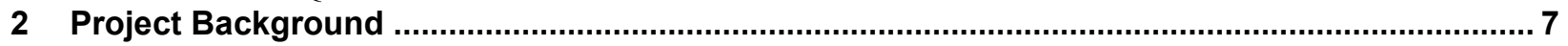

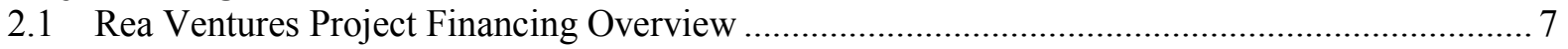

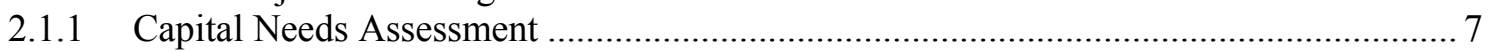

2.1.2 Georgia Power Home Energy Improvement Program ............................................ 7

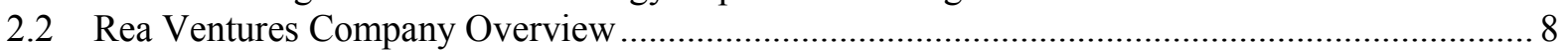

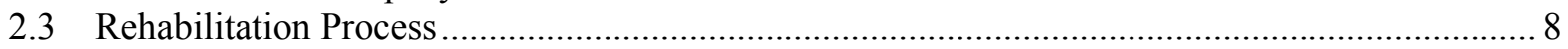

2.4 Rea Ventures U.S. Department of Agriculture Portfolio Information ..................................... 8

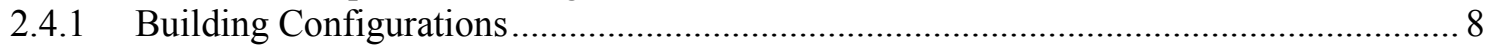

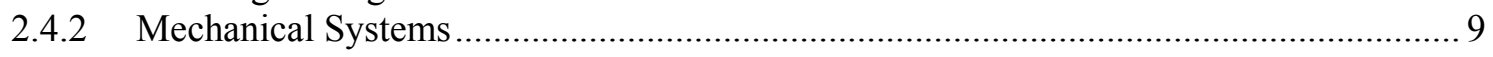

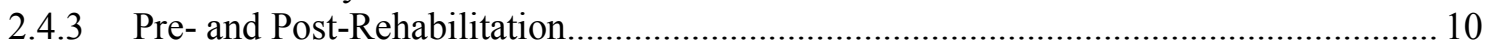

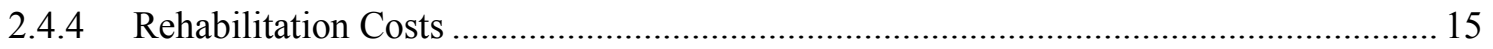

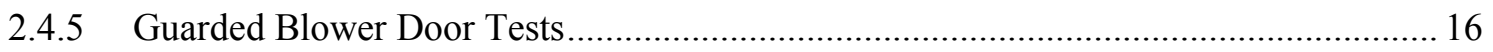

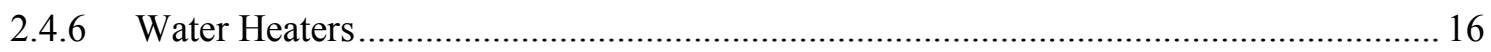

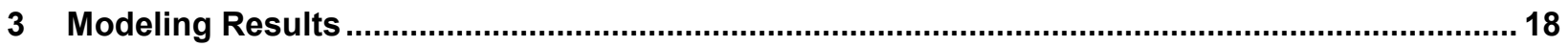

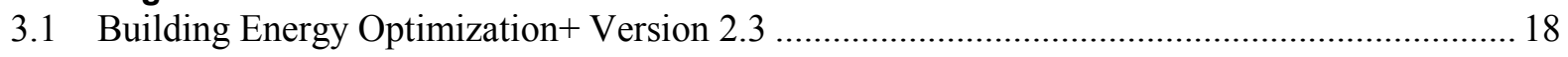

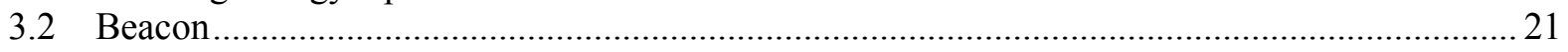

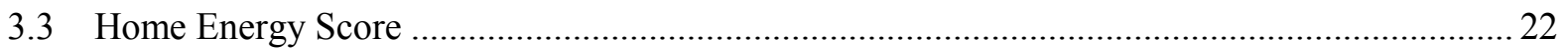

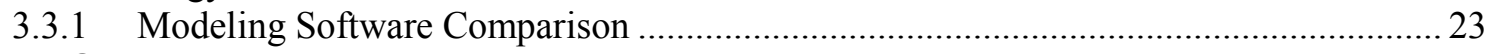

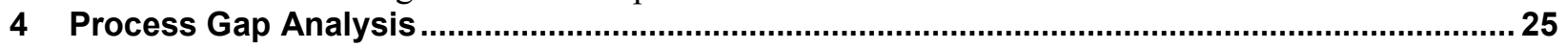

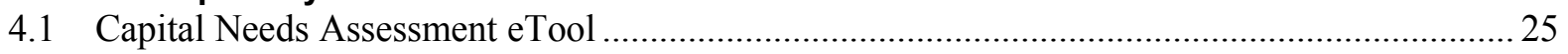

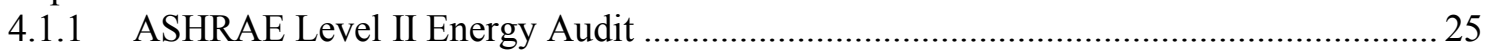

4.1.2 Utility Consumption Baselines, Benchmarking, and Energy Scoring …...................... 25

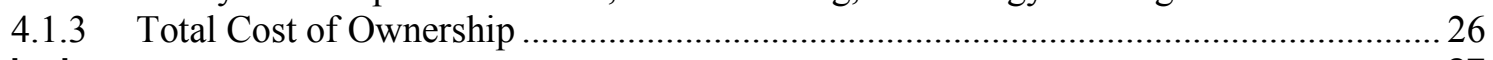

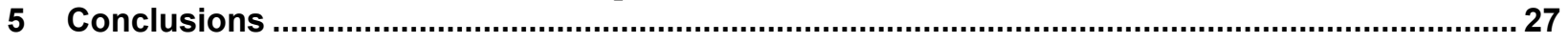

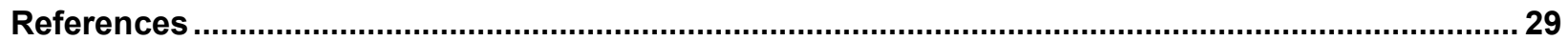




\section{List of Figures}

Figure 1. Map of Georgia showing eligible and ineligible (brown) areas for USDA funding ................... 2

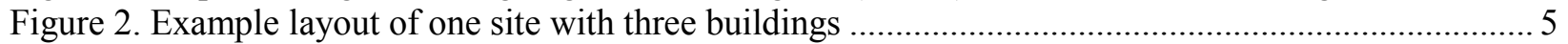

Figure 3. Example of a single building with a combination of flats and townhouses................................ 5

Figure 4. Front view of typical building containing both flat (three-bedroom on left; one-bedroom on right) and townhouse units ............................................................................................... 9

Figure 5. Mechanical equipment inside utility closet pre-rehabilitation................................................. 10

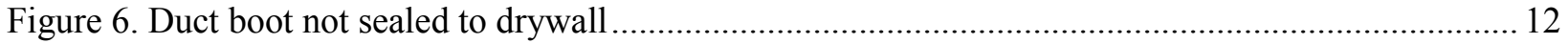

Figure 7. Thermal image of attic hatch when the induced building pressure is $-50 \mathrm{~Pa}$........................... 14

Figure 8. Penetrations in kitchen walls indicate the top plates were unsealed for light switches and outlets above kitchen counter (left); sink plumbing penetrations below counter (right) .................. 14

Figure 9. Thermal images of kitchen cabinets with doors open: above kitchen hood vent showing exhaust duct (left); open cabinet next to a closed cabinet (right) ....................................................... 14

Figure 10. Configuration for guarded blower door test of center unit ................................................. 16

Figure 11. Distribution of water heater delivery temperatures pre- and post-rehabilitation...................... 17

Figure 12. Site energy consumption before and after rehabilitations of typical one-bedroom flat............ 18

Figure 13. Site energy consumption before and after rehabilitations of typical three-bedroom flat .......... 19

Figure 14. Site energy consumption before and after rehabilitations of typical two-bedroom townhouse 19

Figure 15. Beacon model electricity costs by month for a three-bedroom flat in Warm Springs.............. 22

\section{Unless otherwise noted, all figures were created by the Partnership for Home Innovation team.}

\section{List of Tables}

Table 1. Georgia 2015 Qualified Allocation Plan Competitive Scoring Rubric

Table 2. Georgia Power Multifamily Whole-House Approach Rebates per Unit

Table 3. Conditioned Square Footage and Volume of the Three Predominant Unit Types......................... 9

Table 4. General Characteristics of Three Predominant Unit Types ................................................... 9

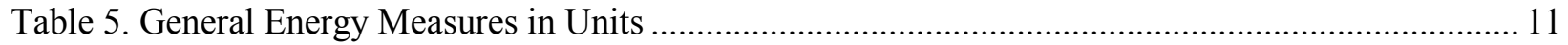

Table 6. Average Pre- and Post-Rehabilitation Performance Test Results at Nine Sites* ...................... 13

Table 7. Cost Data for the Warm Springs Site................................................................................... 15

Table 8. BEopt Modeling Site Energy Consumption Results of the Three-Bedroom Flat and Two-

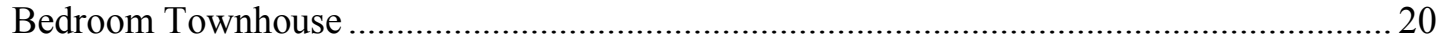

Table 9. BEopt Model Savings of Potential Energy-Efficiency Measures Post-Rehabilitation* .............. 21

Table 10. Warm Springs Beacon Model Energy Savings (kWh) Breakdown by End Use ....................... 21

Table 11. Warm Springs Home Energy Score Model Results............................................................... 23

Table 12. Comparison of Pre-Rehab Actual to Modeled Annual Electricity Costs................................... 24

Unless otherwise noted, all tables were created by the Partnership for Home Innovation team. 


\section{Definitions}

$\mathrm{ACH}_{50}$

Beacon

BEopt ${ }^{\mathrm{TM}}$

BPI

$\mathrm{CFM}_{25}$

$\mathrm{CFM}_{50}$

CNA

DOE

EF

GPM

HEIP

HFA

HSPF

HUD

HVAC

LIHTC

SEER

SOW
Air Changes per Hour at 50 Pascals, infiltration measurement

Building Energy Analysis Console

Building Energy Optimization software

Buildings Performance Institute

Cubic Feet per Minute at 25 Pascals, duct leakage measurement

Cubic Feet per Minute at 50 Pascals, infiltration measurement

Capital Needs Assessment

U.S. Department of Energy

Energy Factor (domestic hot water efficiency)

Gallons per Minute

Home Energy Improvement Program

Housing Finance Agency

Heating Seasonal Performance Factor, heating efficiency

U.S. Department of Housing and Urban Development

Heating, Ventilating, and Air Conditioning

Low Income Housing Tax Credit

Seasonal Energy Efficiency Ratio, cooling efficiency

Scope of Work 


\section{Executive Summary}

Rea Ventures Group, LLC (Rea Ventures) partnered with Southface Energy Institute (Southface) - a member of the U.S. Department of Energy's Partnership for Home Innovation Building America research team - to rehabilitate 418 low-income multifamily rental apartments located at 14 properties in Georgia (International Energy Conservation Code Climate Zones 24 ). These 22-year-old units with individual utility meters were arranged in row house or townhouse style. Rehabilitation plans were developed using a process prescribed by the U.S. Department of Agriculture (USDA) Rural Development program, which partially funded the building upgrades. The USDA is responsible for building, upgrading, and subsidizing housing in rural areas nationwide; this housing includes more than 14,000 existing multifamily housing developments. In 2012, more than $\$ 100$ million in grants and loans were allocated for that purpose.

The research described in this report holds great potential to significantly improve the process for including energy efficiency in developing and implementing federally funded multifamily rehabilitation projects through the USDA, the U.S. Housing and Urban Development (HUD) Low Income Housing Tax Credit, and other programs. Capital Needs Assessments (CNAs) are used to develop scopes of work (SOWs) for preserving and rehabilitating affordable housing funded by the USDA and HUD. The purpose of the CNA is to assess the condition of the property and develop an SOW that includes rehabilitation costs.

Because these properties have unique financing mechanisms and long-term ownership requirements, property owners are especially motivated to invest in upgrades that will increase durability and tenant retention-but energy-efficiency measures are not emphasized. For instance, parking lot, sidewalk, siding repair, and carpet and kitchen cabinet replacement are standard. Yet, these buildings represent a large stock of rural affordable housing that has the potential for significant energy and cost savings for property owners and tenants.

Southface has analyzed the energy-upgrade potential of one typical property in the Rea Ventures portfolio. With the standard Rea Ventures measure package, this property is predicted to achieve $11 \%-15 \%$ source and site energy savings compared to the existing building conditions.

Additional savings greater than $30 \%$ may be possible if certain equipment space constraints and additional barriers can be overcome - for instance, reconfiguring the space to accommodate a heat pump water heater rather than a standard electric resistance tank lowboy water heater. In addition to assessing energy-efficiency measure packages, Southface is working with Rea Ventures to examine its novel financing and business model. Through a combination of public and private financing, Rea Ventures has developed a system to retrofit entire properties during the course of a week, which saves property owners the costs related to tenant relocation, holding, security, and other associated matters.

The standard Rea Ventures package includes: upgrades to the heating, ventilating, and air conditioning so that the seasonal energy efficiency ratio is 14.5 and the heating seasonal performance factor is $8.2 ; 100 \%$ compact fluorescent and linear fluorescent lamps; R-38 blown attic insulation; WaterSense plumbing fixtures; an electric water heater with an energy factor of 0.93; and windows with a U-factor of 0.33 and solar heat gain coefficient of 0.26 . The most costeffective energy-efficiency measure that was overlooked was enclosure air sealing. Postrenovation air leakage even occasionally increased because holes were introduced when the 
kitchen cabinets were replaced. Plumbing and electrical penetrations and air handling units were also not sealed after renovations. Other opportunities were missed because the package did not include components such as higher-efficiency lighting (e.g., light-emitting diode fixtures), higher-efficiency appliances (e.g., refrigerators), and higher-efficiency heat pumps. For instance, upgrading to an air conditioner with a seasonal energy efficiency ratio of 16 would have achieved greater than $20 \%$ total savings. However, the developer was challenged to implement any of these upgrades because of the process used to develop the SOW and secure funding. A critical flaw is that equipment and building energy efficiency is not considered until after the SOW is approved and funds are allocated. At that point, few if any changes can be made. If a building science professional had assessed the building and provided upgrade recommendations that could have been incorporated into the SOW, an additional $10 \%-15 \%$ energy savings could have been achieved. Analysis suggests that the majority of the savings achieved on these projects come from meeting federal appliance standards and Georgia energy code upgrades, because these homes were originally constructed in 1993, when appliance standards and energy codes were much less stringent.

HUD and the USDA have aligned their efforts to improve their current CNA process to incentivize energy-efficiency measures. Residents have lower utility bills when highperformance measures are implemented, but owners cannot necessarily charge higher rents to recoup the additional cost of the measures - often referred to as a "split incentive." The new process is employed via the Multifamily Accelerated Processing Guide and eTool. This approach attempts to rectify the split-incentive by rewarding projects with favorable underwriting terms and allowing owners to raise rents to reward them for lower utility bills. The current draft guidelines require revision to be most useful to this building type, which is common in the Southeast.

Rea Ventures has found that green-certified buildings are of superior quality and provide a secure investment vehicle through the tax credit syndication process. That is, when the company receives a Low Income Housing, New Markets, Historic, or Renewable Energy Tax Credit, it can sell that tax credit to investors to offset the investors' own federal tax liabilities. The tax credits have a superior value because the marketplace perceives that energy-efficient and green-certified buildings have superior quality and provide a more secure investment vehicle. 


\section{Introduction}

The Low Income Housing Tax Credit (LIHTC) is a U.S. Department of Housing and Urban Development (HUD) program for creating and maintaining affordable housing. It was created by the Tax Reform Act of 1986 and distributes nearly $\$ 8$ billion in tax credits through state and local LIHTC-allocating agencies, called Housing Finance Agencies (HFAs). The tax credits incentivize acquisition, rehabilitation, and construction of rental housing for lower-income households. Each HFA has flexibility in how they choose to allocate these tax credits, and several agencies have incorporated requirements or incentives for energy-efficient and highperformance building practices. Between 1995-2013, an average of 110,000 units were placed in service each year according to HUD's National LIHTC database. Over 2.6 million units have been installed since the program's inception (HUD 2013).

In addition to HUD, the U.S. Department of Agriculture (USDA) administers several housing assistance programs aimed at developers, which include Housing Preservation and Revitalization Demonstration Loans and Grants. This program offers a mix of financial instruments to preserve existing rural rental housing and off-farm labor housing and to maintain safe and affordable rental housing for low-income residents. The portfolio includes more than 14,000 properties nationally. ${ }^{1}$ These programs are administered through state Rural Development offices and the funding totaled more than $\$ 100$ million in 2012. Additional programs make direct loans and loan guarantees. USDA funding is restricted to projects in areas that meet population density requirements; for example, only the brown areas (urban) in Figure 1 are ineligible.

For retrofit projects under the LIHTC and the USDA programs, a third-party Capital Needs Assessment (CNA) is required to identify upgrade needs and associated costs and to specify the equipment/appliance replacement schedule and budget throughout the project life span. Fannie Mae prescriptively defines the content of and process for conducting the CNA, which is designed to comprehensively assess the physical condition of the building and grounds and to provide the data necessary for underwriting financing for upgrade projects. The focus is on the expected useful life, age, remaining useful life, and condition of mechanical equipment and appliances. ${ }^{2}$ However, the CNA does not consider the energy efficiency of the building or mechanical systems - nor does it have mechanisms to compute owner and occupant savings from highperformance upgrades.

\footnotetext{
${ }^{1}$ www.rd.usda.gov/programs-services/all-programs/multi-family-housing-programs

2 www.rd.usda.gov/files/CNA_Worksheet_Ver_0.xls
} 


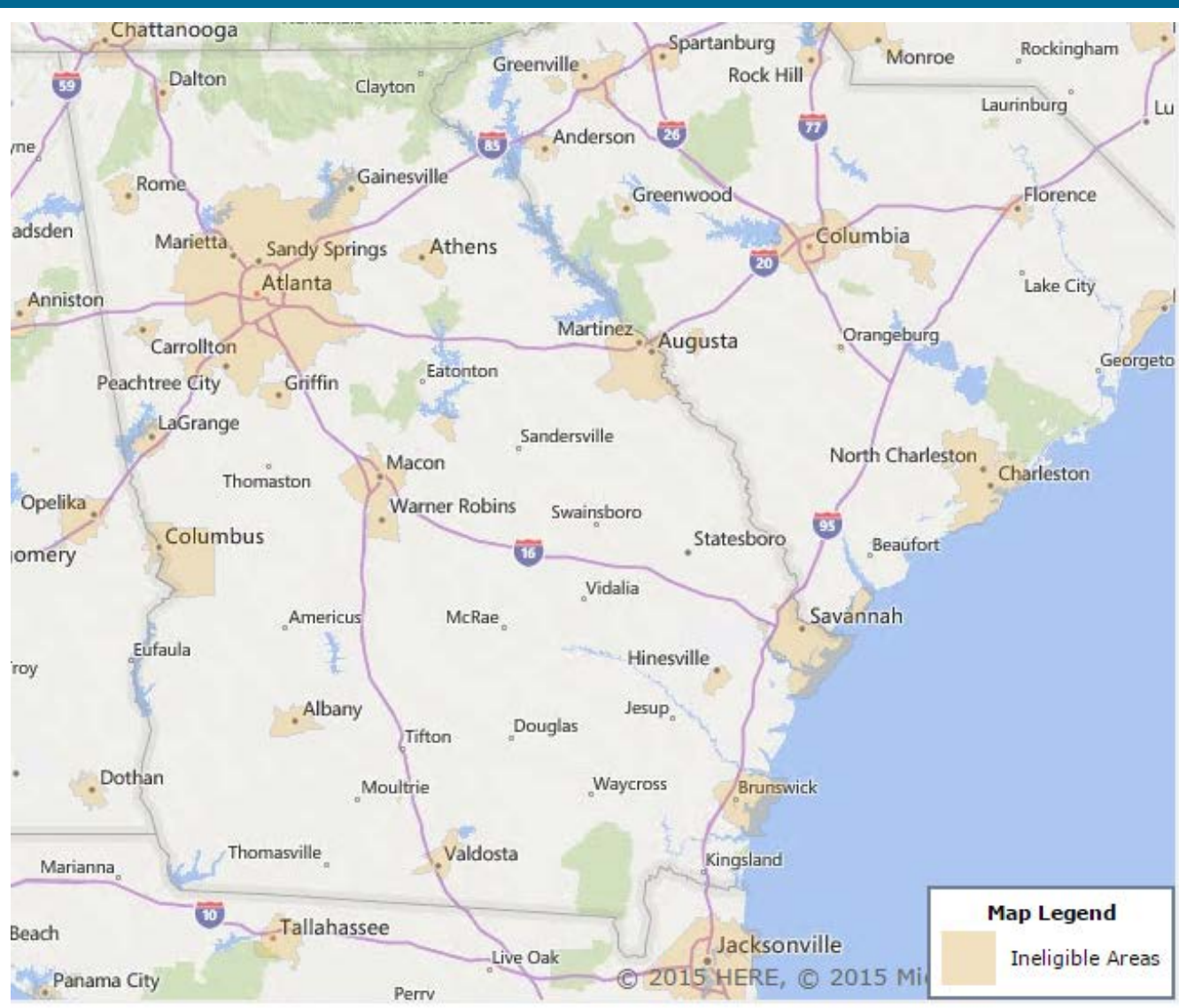

Figure 1. Map of Georgia showing eligible and ineligible (brown) areas for USDA funding ${ }^{3}$

\subsection{Problem Statement}

In Georgia, the LIHTC is administered by the Georgia Department of Community Affairs through the Qualified Allocation Plan, which is a merit-based system with 93 achievable points in the 2015 round. ${ }^{4}$ Southface Energy Institute (Southface) is a member of the U.S. Department of Energy's Partnership for Home Innovation Building America research team. Southface partnered with the Department of Community Affairs to incorporate energy-efficient and sustainable building requirements into the Qualified Allocation Plan. This effort is aimed at ensuring that affordable housing includes affordable utilities for residents and durable buildings for developers who typically must retain ownership for 15 years post-occupancy. In Georgia, multifamily new construction buildings - not rehabilitation projects - must meet minimum thresholds for duct and envelope leakage, bathroom fans, lighting efficiency, plumbing fixtures, wall and floor finishes with low volatile-organic-compound content, water heater efficiency, ENERGY STAR ${ }^{\circledR}$ appliances, and minimum 30-year warranty products for siding and roofing. The plan makes 93 optional points available through competitive scoring criteria (Table 2) to rank proposals. Among these optional points, 4 are available in the Sustainable Developments category; 3 points are available for either EarthCraft Communities ${ }^{5}$ or Leadership in Energy \& Environmental Design Neighborhood Developments; OR 2 points are available for EarthCraft

\footnotetext{
${ }^{3}$ http://eligibility.sc.egov.usda.gov/eligibility/welcomeAction.do

${ }^{4}$ www.dca.ga.gov/housing/HousingDevelopment/programs/documents/2015QualifiedAllocationPlan_001.pdf

5 www.earthcraft.org/builders/programs/earthcraft-communities/
} 
Multifamily, Enterprise Community's Green Communities, Leadership in Energy \& Environmental Design for Homes, National Green Building Standard Silver or higher, or ENERGY STAR; and 1 point is available for an Integrated Design Review Charrette. Thus, energy-efficient construction practices account for $4.3 \%$ of the total available points in the Qualified Allocation Plan. In 2013, Global Green USA conducted a performance ranking analysis of sustainable building practices that were promoted by each state's Qualified Allocation Plan and ranked Georgia's 10th best in the nation (Fuhry, DeCoursey, and Wells 2013).

Table 1. Georgia 2015 Qualified Allocation Plan Competitive Scoring Rubric

\begin{tabular}{|c|c|}
\hline Competitive Scoring Category & Available Points \\
\hline Application Completeness & 10 points \\
\hline Deeper Targeting/Rent/Income Restrictions & 3 points \\
\hline Desirable Activities/Undesirable & 13 points \\
\hline Community Transportation Options & 5 points \\
\hline Brownfield & 2 points \\
\hline Sustainable Developments & 4 points \\
\hline Stable Communities & 4 points \\
\hline Revitalization/Redevelopment Plans & 3 points \\
\hline Phased Development/Previous Projects & 4 points \\
\hline Market Characteristics & 2 points \\
\hline Extended Affordability Commitment & 1 point \\
\hline Exceptional Nonprofit & 3 points \\
\hline Rural Priority & 3 points \\
\hline Department of Community Affairs Initiatives & 1 point \\
\hline Leveraging of Public Resources & 8 points \\
\hline Innovative Project Concept & 3 points \\
\hline Integrated Supportive Housing & 3 points \\
\hline Historic Preservation & 2 points \\
\hline Preservation Priority & 5 points \\
\hline Quality Education Areas & 2 points \\
\hline Workforce Housing Need & 2 points \\
\hline Compliance/Performance & 10 points \\
\hline Total & 93 points \\
\hline
\end{tabular}

Although the plan goals are laudable, the plan does not permit an integrative design process for renovation projects. This is not unique to Georgia.

The Qualified Allocation Plan requires a CNA or Physical Needs Assessment to be conducted on all rehabilitation, preservation, and adaptive reuse projects before the funding application is submitted, and the scope of work (SOW) must address all major findings. No changes in SOW are allowed after the tax credit award.

The CNA or Physical Needs Assessment that is used to create the SOW for the application does not include an assessment of potential energy-efficiency upgrades. Therefore, opportunities may be lost during federally-funded upgrades to affordable housing. Furthermore, building science professionals are typically not brought into the processes through green building certification 
programs until projects are funded, and by that time no changes in SOWs are permitted. At that point, the consultants' expertise and tools are underutilized.

Similarly, the process for funding USDA projects does not incorporate energy-efficiency upgrades. If a building science professional is brought onto the team, it is after the SOWs are approved and funded.

An additional layer of complexity involves setting rental rates. Total monthly housing costs for tenants include rent and utilities (energy, water, and sewer). In federally subsidized affordable housing, these costs are based on a rate that is set either as a percentage of the area's median income or as a percentage of the tenant's adjusted monthly income — depending on the program through which the subsidy is provided. The amount allocated for tenant-paid utilities is known as the utility allowance.

\section{Total housing costs $=$ Rent + Utility allowance $=$ factor $\times$ Area median income}

The tenant pays the property owner the difference between the total housing cost and the utility allowance. Historically, utility allowances have been determined by regional rates and average consumption data and do not account for energy-efficiency upgrades that lower tenants' out-ofpocket expenses; therefore, developers have little incentive to implement measures because rental rates are capped by fixed total housing costs and utility allowances. Once the building has been in operation for two full years, the owner can submit utility bills to the HFA as evidence of lower utility expenses to request higher rent. However, obtaining utility bills from each tenant is often difficult-especially given tenant turnover. Also, in rural areas it is often not economically feasible to increase rents because many rental markets are depressed and prospective renters often consider only rent and not total housing costs when shopping for housing.

Because projects funded by the LIHTC and USDA Rural Development require that the developer maintain ownership for a significant period of time, typically 10-15 years, measures that improve durability, maintainability, and energy efficiency of common spaces have a direct impact on the developer's bottom line. If alternative methods are used to compute rent which account for energy efficiency measures, this 15 -year time span may provide sufficient time to recoup investment costs $^{6}$.

\subsection{Project Overview}

Southface partnered with Atlanta-based multifamily developer Rea Ventures Group, LLC (Rea Ventures) to increase the value of its properties by improving its current building specifications by incorporating increased energy-efficiency and durability measures. The approach was to analyze the energy-efficiency potential of a recently acquired portfolio of properties across rural Georgia and develop a cost-optimized energy-efficiency solution that could be deployed statewide and create the best value for the property owners and the residents. These rehabilitations are being funded through the USDA Rural Development program, private investments, and utility energy-efficiency incentives. The entire portfolio consists of 14 individual properties - each with multiple buildings (see example in Figure 2). The total

\footnotetext{
${ }^{6} \mathrm{http}: / /$ www.enterprisecommunity.com/policy-and-advocacy/issues/green-and-sustainable-housing-andcommunities/utility-allowances
} 
portfolio contains 418 housing units. The properties comprise buildings that are combinations of two- to eight-unit row houses (see example in Figure 3).

Initial SOWs were developed by Rea Ventures and approved by the USDA based on CNAs conducted by a third party. These properties are not required to achieve green building certification or energy-efficiency improvement thresholds. Southface performed an additional analysis to determine the critical gaps between the CNA process used on this project and an assessment and SOW development process for a comprehensive energy-efficiency upgrade.

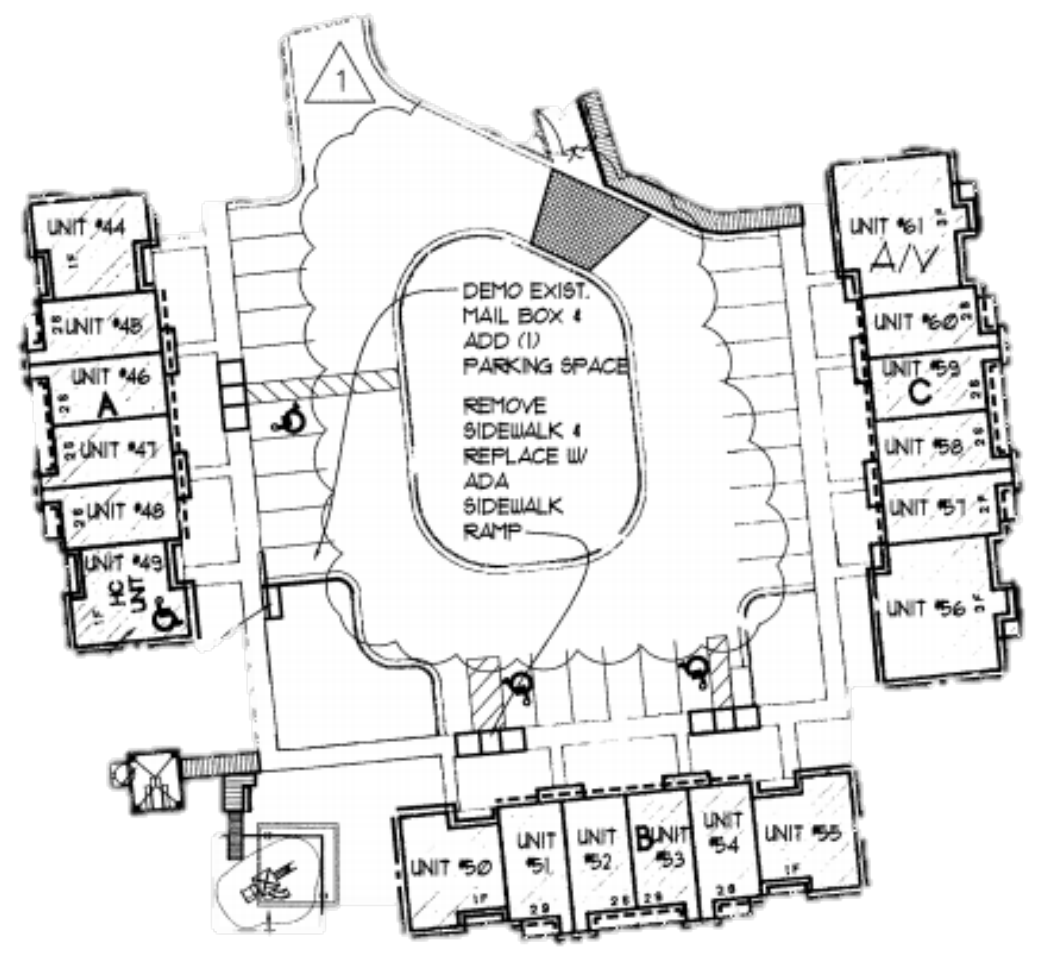

Figure 2. Example layout of one site with three buildings

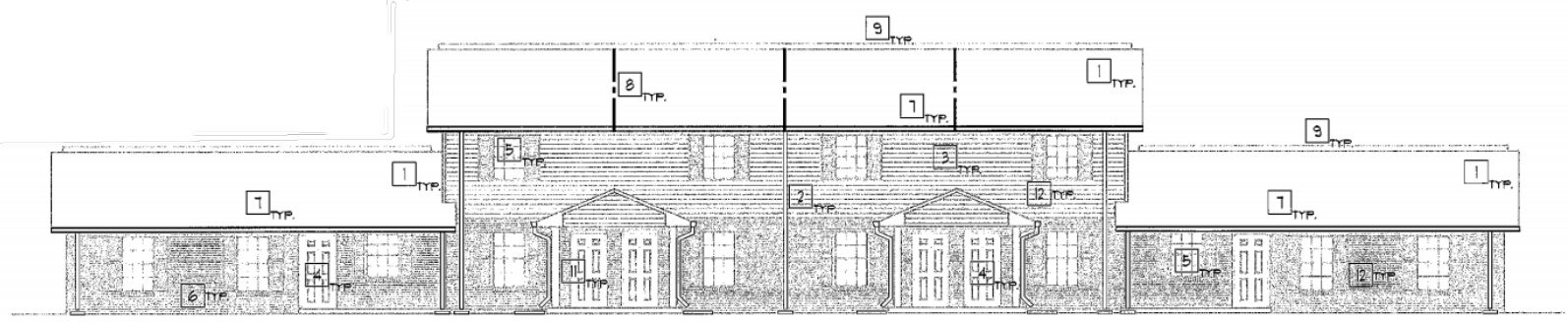

Figure 3. Example of a single building with a combination of flats and townhouses

\subsection{Research Questions}

Several research questions have been identified that include policy and technical issues. Technical details of the Rea Ventures rehabilitation experience will be used as examples to demonstrate universal barriers and program potential. 
- How does the CNA information differ from the researchers' energy assessment? What additional information is needed to capture energy savings potential and create an SOW?

- How do the priorities identified in the CNA align with the energy-efficiency measures suggested by Building Energy Optimization (BEopt ${ }^{\mathrm{TM}}$ ) simulations and expert judgment?

- What are the training and certification needs for incorporating energy-efficiency assessment into the current CNA and USDA funding processes?

- Does the funding process of affordable housing rehabilitations present barriers that restrict the implementation of energy-efficiency measures? What steps could be taken to remove these barriers? 


\section{Project Background}

\subsection{Rea Ventures Project Financing Overview}

The two primary funding drivers for this project were:

- The USDA Rural Development funding, which was based on SOWs that were developed from third-party CNAs

- Incentives available through the electric utility demand-side management program.

\subsubsection{Capital Needs Assessment}

The CNAs were conducted by EMG, a national firm specializing in real estate due diligence services. The CNAs were performed at the request of Rea Ventures in accordance with the client-supplied SOW defined in the USDA Rural Development Multi-Family Housing Program's Unnumbered Letter dated August 7, 2012, "Guidance on the Capital Needs Assessment Process." 7 The reports were prepared in accordance with Fannie Mae Document FNMA, Delegated Underwriting Services Guide Section 3 entitled "Physical Needs Assessment Guidance to the Property Evaluator." 8 The SOWs outlined by the CNA formed the basis for the Rural Development award amount and could not be revised after award. Scopes of work met Georgia Energy Code requirements.

\subsubsection{Georgia Power Home Energy Improvement Program}

Georgia Power Company offers incentives for residential energy-efficiency upgrades of existing single-family and multifamily properties through its Home Energy Improvement Program (HEIP). Georgia Power is a subsidiary of Southern Company and is the largest electric utility in Georgia; it serves more than 2.1 million residential customers. The HEIP offers maximum incentives for comprehensive improvements that are verified by certified Building Performance Institute (BPI) Building Analyst Professionals through test-in and test-out procedures and energy modeling using Building Energy Analysis Console (Beacon) energy simulation and analysis modeling software provided by utility implementation contractor ICF International. Incentives were provided that were a percentage of installed energy efficiency measure cost, based on projected annual electricity use reduction and additional optional measures (Table 2). The maximum available incentive per unit is $\$ 1,100$. Incentives are different but follow a similar pattern for single-family homes.

Table 2. Georgia Power Multifamily Whole-House Approach Rebates per Unit

\begin{tabular}{c|c}
\hline Rebate Item & Multifamily Rebate \\
\hline $\mathbf{2 0 \%} \mathbf{k W h}$ Savings & $50 \%$ up to $\$ 625$ \\
$\mathbf{2 5 \%} \mathbf{k W h}$ Savings & $50 \%$ up to $\$ 725$ \\
$\mathbf{3 0 \%} \mathbf{k W h}$ Savings & $50 \%$ up to $\$ 925$ \\
BPI Assessment & $50 \%$ up to $\$ 100$ \\
Programmable Thermostat & $50 \%$ up to $\$ 50$ \\
Electric Water Heater Tank Wrap & $50 \%$ up to $\$ 25$ \\
\hline Maximum Total & $\$ 1,100$ \\
\hline
\end{tabular}

${ }^{7}$ www.rd.usda.gov/files/IA_hp_mfh_CNA_Guidance_ul_08-07-12.pdf

${ }^{8}$ www.fanniemae.com/content/guide_form/iii-12.pdf 
The HEIP allows strategic sampling of units in multifamily buildings during test-in and test-out procedures. A sampling plan must be preapproved by ICF International and include a minimum of $15 \%$ of total units with at least one unit of each type and one unit on each floor. Failure of a gas appliance combustion safety test will trigger $100 \%$ testing of all units in the building with the failure.

Rea Ventures incurred costs in hiring a firm to coordinate between Rea Ventures and Georgia Power, manage the field verifications with BPI-certified staff, perform the Beacon energy simulation models, and collect and submit construction cost invoices with the rebate forms. Even so, the HEIP provided substantial additional cash that could be used to achieve the targeted savings. Typical assessment contractor costs are $25 \%-33 \%$ of total rebates, depending on building sizes, locations, and potential presence of combustion appliances.

The HEIP provided incentives for Rea Ventures to upgrade its rehabilitation SOW by installing 14.5 seasonal energy efficiency ratio (SEER) heat pumps and screw-in compact fluorescent lamps. The focus was on measures that would achieve savings thresholds in the Beacon software to earn rebates.

\subsection{Rea Ventures Company Overview}

Rea Ventures is a developer of affordable and market-rate multifamily housing across the Southeast. It has developed more than 3,500 units of multifamily housing and specializes in affordable workforce, disabled, and senior housing that uses LIHTC and USDA programs, which include long-term ownership of the rent-restricted properties. The company prioritizes energy efficiency and healthy indoor environments, which are often delivered through green building certification programs as components of Rea Ventures' corporate philosophy.

\subsection{Rehabilitation Process}

Rea Ventures employs a process of rehabilitating facilities with residents in place. Rehabs typically include kitchen cabinets; countertops; appliances; flooring; all lighting; carpets; windows; doors; paint; attic insulation; heating, ventilating, and air-conditioning (HVAC) units; and water heaters. The residents are instructed to move their belongings to the center of impacted rooms in the morning, and the contractors protect and work around their belongings. A property can be rehabbed in approximately 1 week.

\subsection{Rea Ventures U.S. Department of Agriculture Portfolio Information}

All the properties in this 14-site portfolio in rural Georgia are designated as low-income housing. They consist of all-electric multifamily buildings that contain two to eight units, depending on the site. The largest site contains 52 units and the smallest contains 18 units (average of $30 \pm 10$ ). The sites were constructed in the early 1990s.

\subsubsection{Building Configurations}

All buildings are row house or townhouse style. Individual units share vertical common walls and no units are stacked vertically. Typically, each building includes a one-bedroom flat and a three-bedroom flat end unit with multiple two-bedroom, two-story townhouses between (Figure 4). Some buildings consist of all one-bedroom flats, and others were all two-bedroom two-story townhouses. No buildings consist of only three-bedroom flats. A few properties had one 
Americans with Disabilities Act-compliant two-unit building consisting of two-bedroom flats. The leasing office at each site is the size of a one-bedroom flat but has a different interior layout and is adjacent to a laundry facility. Unit sizes and general characteristics are listed in Table 3 and Table 4, respectively.

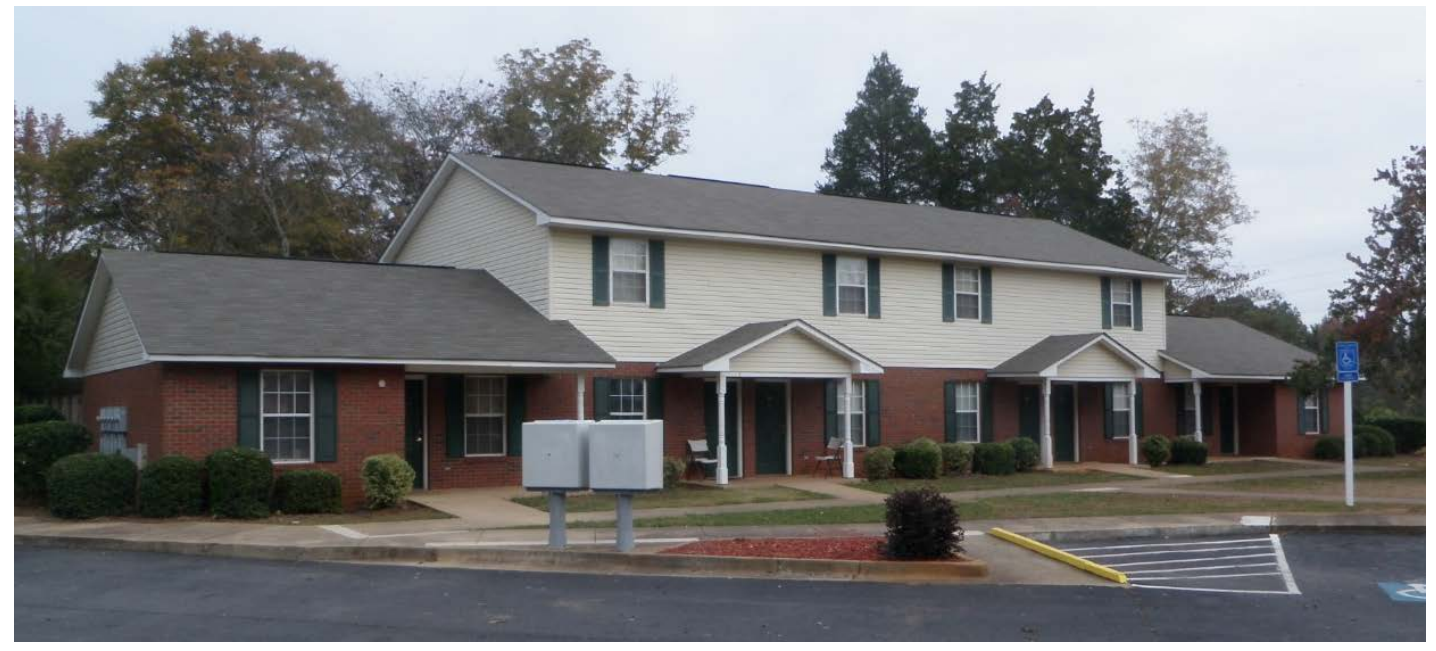

Figure 4. Front view of typical building containing both flat (three-bedroom on left; one-bedroom on right) and townhouse units

Table 3. Conditioned Square Footage and Volume of the Three Predominant Unit Types

\begin{tabular}{c|c|c}
\hline Type & Area $\left(\mathbf{f t}^{\mathbf{2}}\right)$ & Volume $\left(\mathbf{f t}^{\mathbf{3}} \mathbf{)}\right.$ \\
\hline One-Bedroom & 590 & 4,720 \\
Three-Bedroom & 905 & 7,240 \\
Townhouse & 900 & 7,293 \\
\hline
\end{tabular}

Table 4. General Characteristics of Three Predominant Unit Types

\begin{tabular}{|c|c|c|c|}
\hline Description & One-Bedroom Flat & Three-Bedroom Flat & Two-Bedroom TH \\
\hline Ceiling Height & \multicolumn{3}{|c|}{$8 \mathrm{ft}$ in rooms; $7 \mathrm{ft}$ in hallway with $1 \mathrm{ft}$ plenum housing ducts } \\
\hline $\begin{array}{l}\text { Exterior Window } \\
\text { Count }\end{array}$ & $\begin{array}{l}2 \times(35 \text { in. } \times 56 \text { in. }) \\
1 \times(35 \text { in. } \times 50 \text { in. }) \\
1 \times(35 \text { in. } \times 35 \text { in. })\end{array}$ & $\begin{array}{l}3 \times(35 \text { in. } \times 56 \text { in. }) \\
1 \times(35 \text { in. } \times 50 \text { in. }) \\
1 \times(35 \text { in. } \times 35 \text { in. })\end{array}$ & $\begin{array}{l}2 \times(36 \text { in. } \times 60 \text { in. }) \\
2 x(36 \text { in. } \times 51 \text { in. })\end{array}$ \\
\hline Exterior Doors & 2 & 2 & 2 \\
\hline $\begin{array}{c}\text { Exterior Wall } \\
\text { Insulation }\end{array}$ & \multicolumn{3}{|c|}{ R-13 fiberglass batt insulation } \\
\hline Foundation Type & \multicolumn{3}{|c|}{ Uninsulated slab } \\
\hline Exterior Cladding & \multicolumn{3}{|c|}{ Brick veneer lower; vinyl siding upper } \\
\hline Washer/Dryer & \multicolumn{3}{|c|}{ Tenant owned; laundry facility at each site } \\
\hline Oven & \multicolumn{3}{|c|}{ Electric range/oven } \\
\hline Ducts & \multicolumn{3}{|c|}{ Rigid ducts located in hallway plenum below attic insulation } \\
\hline
\end{tabular}

\subsubsection{Mechanical Systems}

Each apartment has an air-handling unit and an electric water heater in a utility closet. The heat pump had an open return with a filter. Supply ducts branch off into a dropped soffit. The electric 
water heater is positioned directly below the air handling unit. The HVAC filter rack was positioned at the base of the air handler, making it difficult to visually inspect and to change the filter.

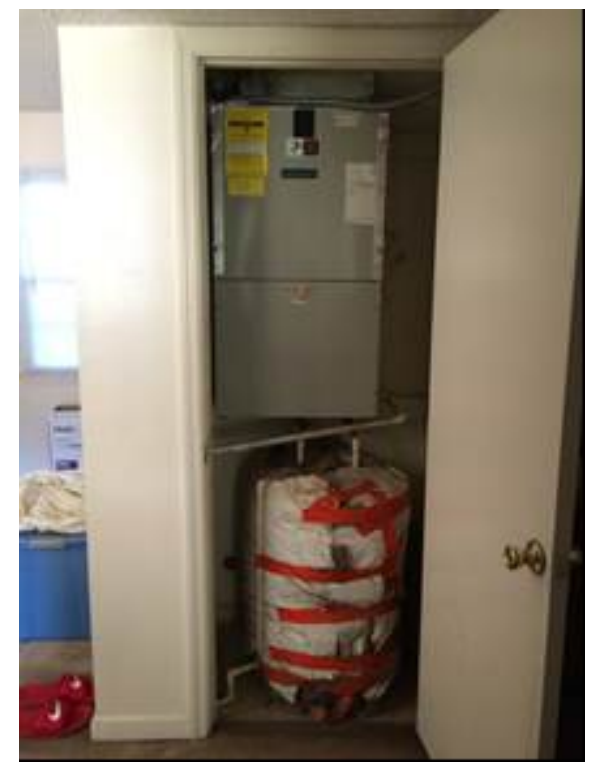

Figure 5. Mechanical equipment inside utility closet pre-rehabilitation

\subsubsection{Pre- and Post-Rehabilitation}

Conditions of energy-efficiency measures pre- and post-rehabilitation are listed in Table 5. Prerehabilitation, the age of the existing $15.5-\mathrm{ft}^{3}$ refrigerators with top freezers varied greatly between units, because many had been replaced in the last 10 years. However, during the rehabilitation all refrigerators were replaced; $57 \%$ were replaced with $15.5-\mathrm{ft}^{3}$ top freezer General Electric ENERGY STAR certified models and 43\% were replaced with Hotpoint top freezer models that were ENERGY STAR certified. The expected average annual energy and cost savings from refrigerator replacements are minimal.

Enclosure and duct airtightness tests were conducted on the same sample of units pre- and postrehabilitation at each site (Table 6). The ducts were in a plenum beneath the attic floor and insulation. There was no measured leakage to the outside. For the rehabilitation process, the ducts were inaccessible to perform duct-sealing measures at connections or along seams. The SOW did not include air sealing of the duct chase from the attic side or sealing the duct boots to the drywall. Inspection revealed significant opportunity for improvement and easy accessibility within the rehabilitation process for sealing the duct boots to the drywall (Figure 6). The replacement of the old air handling unit with a new one is assumed to be the source of the measured changes in total duct leakage. Total duct leakage increased at Warm Springs and Pigeon Bluff. 
Table 5. General Energy Measures in Units

\begin{tabular}{c|c|c}
\hline Description & Pre-Rehabilitation & Post-Rehabilitation \\
\hline Windows & $\begin{array}{c}\text { Double pane; aluminum frame } \\
\text { U } 0.76 \text {; solar heat gain } \\
\text { coefficient } 0.67\end{array}$ & $\begin{array}{c}\text { Double pane; } \\
\text { U } 0.33 \text {; solar heat gain } \\
\text { coefficient } 0.26\end{array}$ \\
\hline Exterior Doors & 1 -3/4-in. metal & 1 -3/4-in. metal insulated \\
\hline Attic Floor Insulation & $\sim 10$-in. blown fiberglass $\sim \mathrm{R}-30$ & 16 -in. blown fiberglass $\sim \mathrm{R}-38$ \\
Grade II
\end{tabular}

* Number depends on floor layout being one-bedroom flat, two-bedroom townhouse, or three-bedroom flat, respectively. 


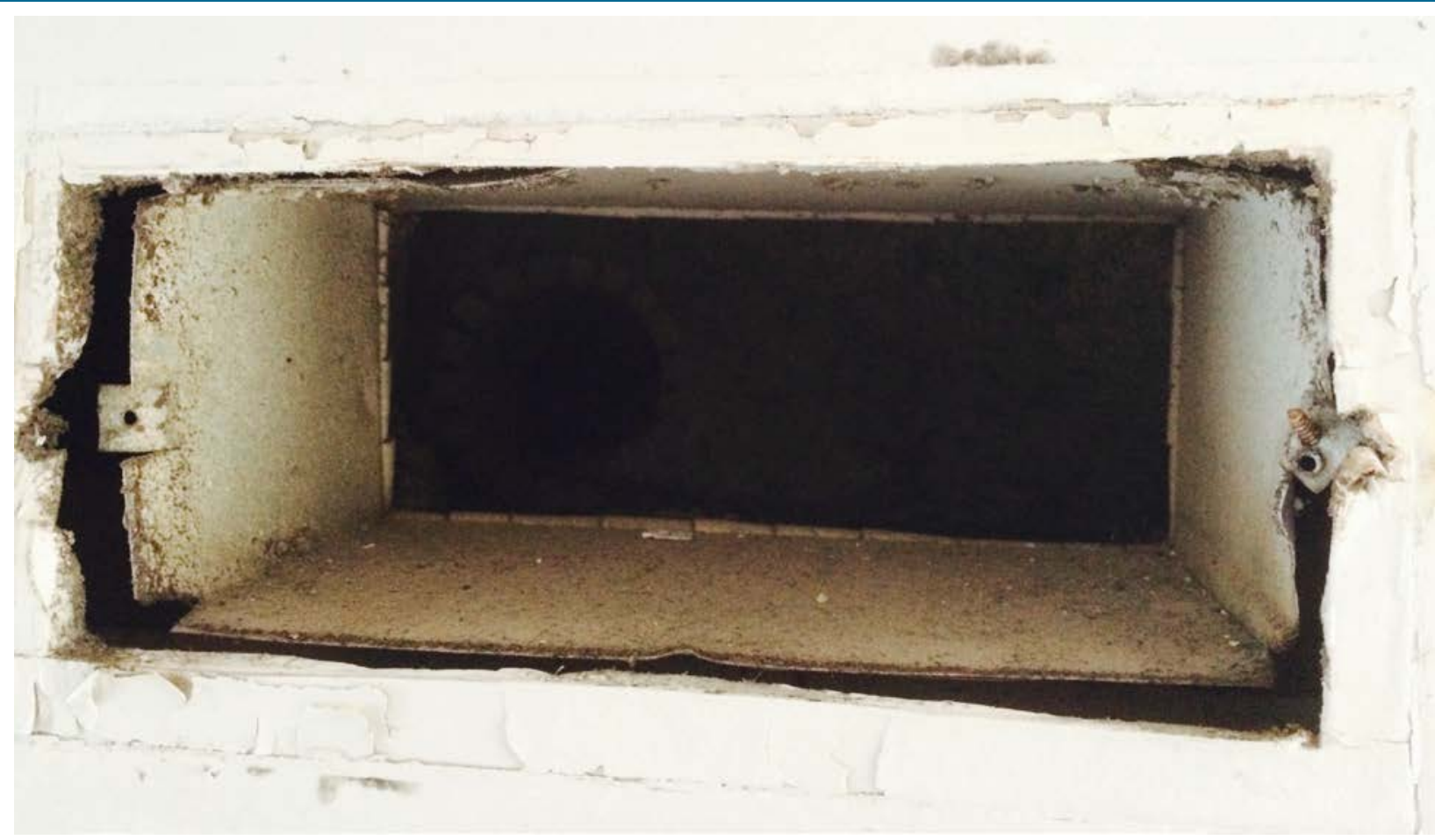

Figure 6. Duct boot not sealed to drywall

Within the SOW, the rehabilitation did not include enclosure air sealing, and none of the tradespeople made conscientious efforts to perform any air-sealing measures. However, replacing the windows and doors did reduce enclosure air leakage in most cases. Improved airtightness was included as a measure in the Beacon energy model and qualified the homes for utility rebates. During the test-out inspection at Hidden Creek, enclosure air leakage significantly increased at the first two units tested. The test-out inspection was halted so air-sealing measures could be performed to qualify the units for HEIP rebates. Although the average envelope leakage at each site decreased, the envelope leakage actually increased in several units. The increase is believed to have been caused from holes in the drywall behind the new kitchen cabinets. Figure 7 through Figure 9 show infrared images of air leakage through the enclosure while the building was depressurized. These images were taken in the winter, and the darker shading indicates cold surfaces where cold air from outside is being drawn in through leaks in the building enclosure. 
Table 6. Average Pre- and Post-Rehabilitation Performance Test Results at Nine Sites*

\begin{tabular}{|c|c|c|c|c|c|c|c|}
\hline Site & $\begin{array}{c}\# \text { of } \\
\text { Units } \\
\text { Tested }\end{array}$ & $\begin{array}{c}\text { Total Duct } \\
\text { Leakage Pre } \\
\left(\text { CFM }_{25}\right)\end{array}$ & $\begin{array}{c}\text { Total Duct } \\
\text { Leakage Post } \\
\left(\text { CFM }_{25}\right)\end{array}$ & $\begin{array}{c}\text { Reduction } \\
(\%)\end{array}$ & $\begin{array}{c}\text { Enclosure Air } \\
\text { Leakage Pre } \\
\text { (CFM50) }\end{array}$ & $\begin{array}{c}\text { Enclosure Air } \\
\text { Leakage Post } \\
\text { (CFM50) }\end{array}$ & $\begin{array}{c}\text { Reduction } \\
(\%)\end{array}$ \\
\hline Warm Springs & 4 & 100 & 123 & -23 & 1,592 & 1,290 & 10 \\
\hline Heritage Manor & 5 & 180 & 114 & 37 & 1,531 & 1,341 & 12 \\
\hline Pigeon Bluff & 3 & 122 & 175 & -43 & 1,469 & 1,429 & 3 \\
\hline Pigeon Creek & 8 & 139 & 111 & 20 & 863 & 819 & 5 \\
\hline Hidden Creek & 12 & 207 & 117 & 43 & 1,063 & 948 & 11 \\
\hline Forest Point & 4 & 115 & 90 & 22 & 1,213 & 1,060 & 13 \\
\hline Pine Brook & 11 & 147 & 132 & 10 & 1,078 & 971 & 10 \\
\hline Fairfield I & 5 & 108 & 98 & 9 & 1,023 & 735 & 28 \\
\hline Fairfield II & 4 & 75 & 58 & 23 & 896 & 709 & 21 \\
\hline
\end{tabular}

* Red indicates an increase in leakage. 


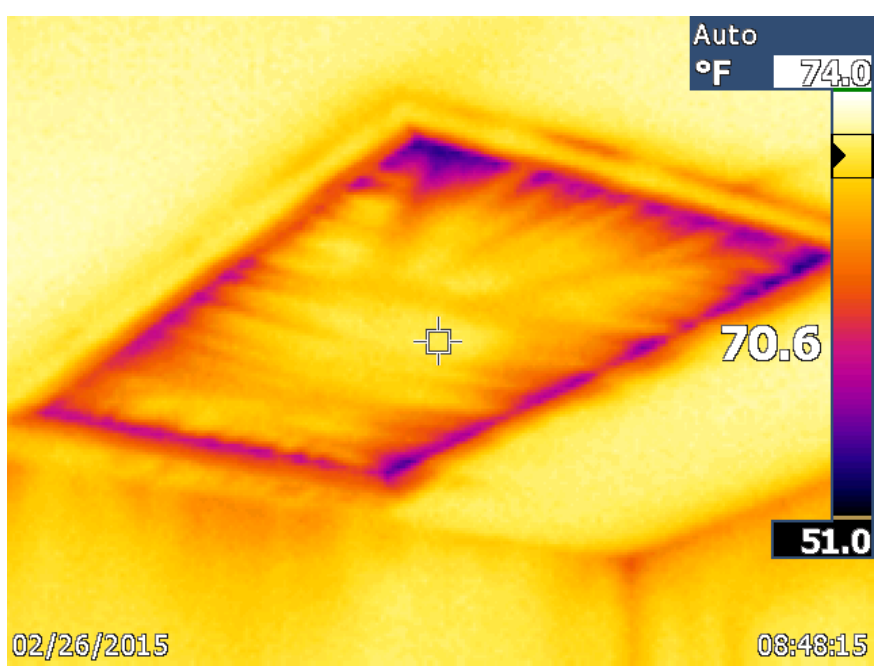

Figure 7. Thermal image of attic hatch when the induced building pressure is $-50 \mathrm{~Pa}$

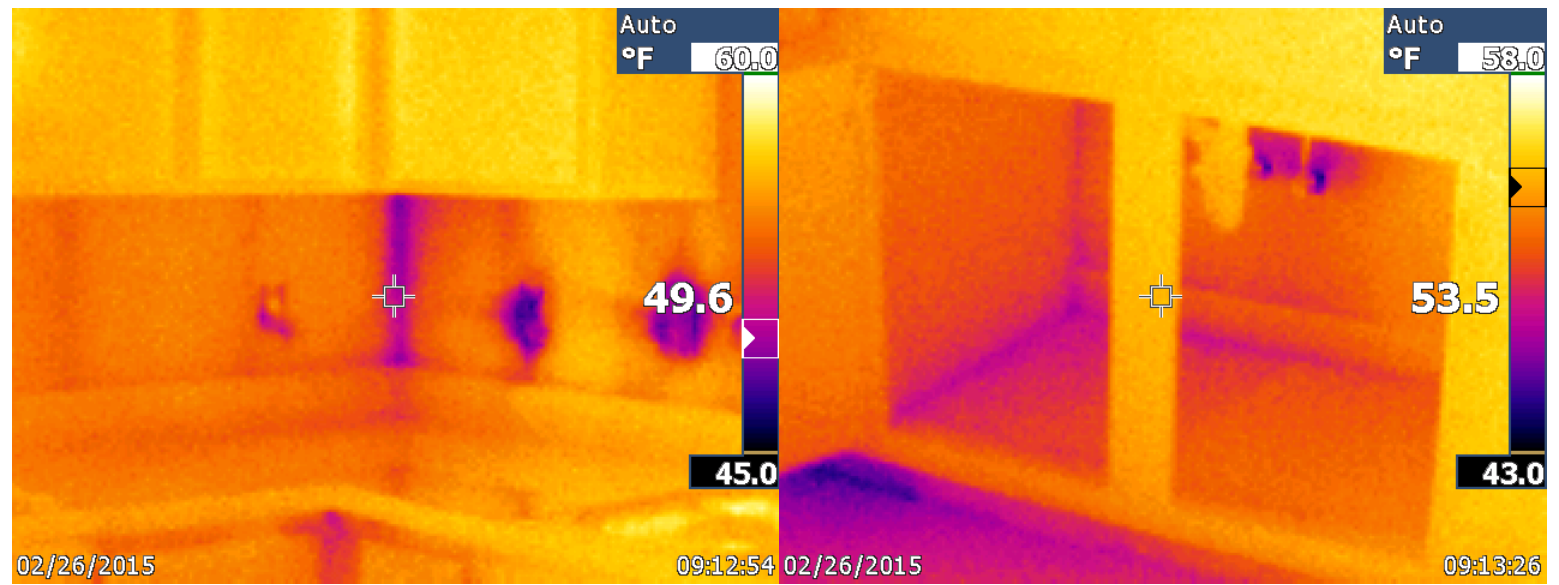

Figure 8. Penetrations in kitchen walls indicate the top plates were unsealed for light switches and outlets above kitchen counter (left); sink plumbing penetrations below counter (right)

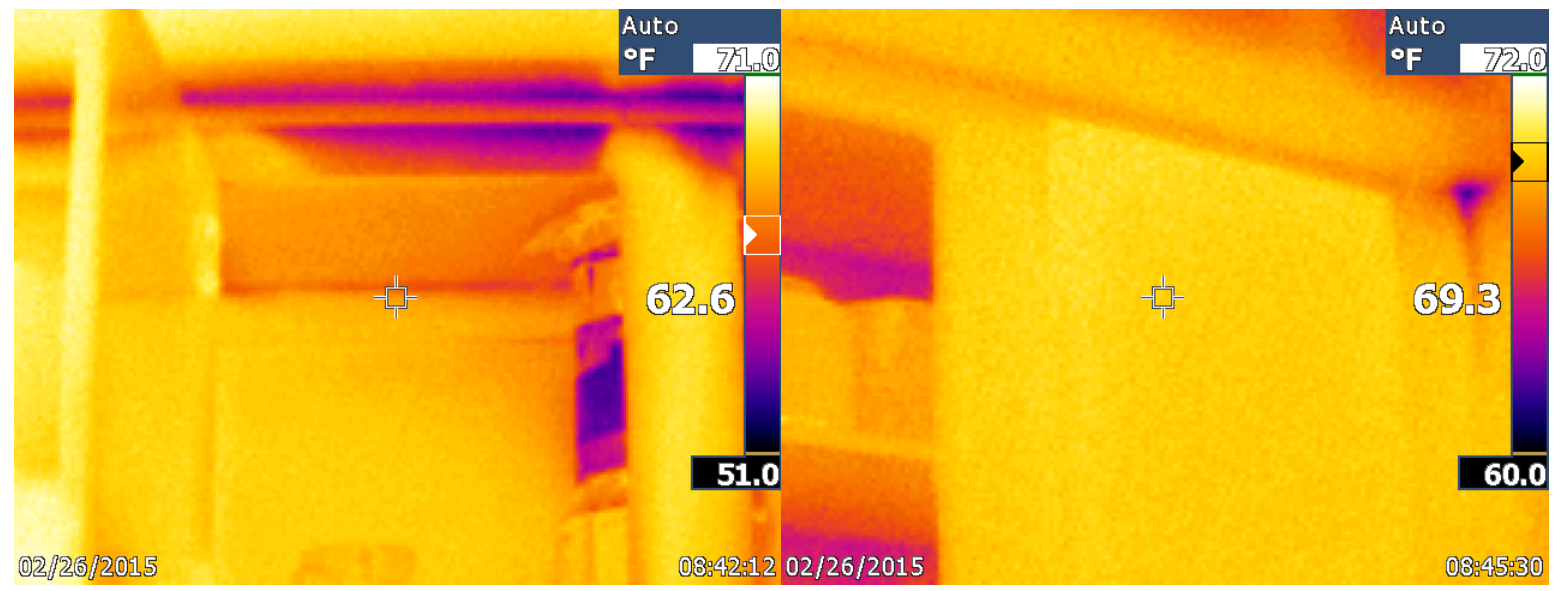

Figure 9. Thermal images of kitchen cabinets with doors open: above kitchen hood vent showing exhaust duct (left); open cabinet next to a closed cabinet (right) 


\subsubsection{Rehabilitation Costs}

Cost data for the entire rehabilitation project are available for the 22 units at the Warm Springs site (Table 7). Including insulation, windows, doors, and HVAC as energy-efficiency measures, these upgrades accounted for $22 \%$ of the total budget. Window and door upgrades $(46 \%$ of the energy-efficiency measure total cost) also improved the aesthetic appeal, comfort, and security of the homes. This list does not include either the expenses or the revenue associated with the utility incentive program.

Table 7. Cost Data for the Warm Springs Site

\begin{tabular}{|c|c|}
\hline Description of Work & Scheduled Value \\
\hline Fire Suppression & $\$ 968$ \\
Masonry & $\$ 1,900$ \\
\hline Blinds & $\$ 2,200$ \\
\hline Rough Carpentry & $\$ 4,950$ \\
\hline Gutters/Downspout & $\$ 5,000$ \\
\hline Specialties & $\$ 7,990$ \\
\hline Siding/Shutters & $\$ 8,300$ \\
\hline Landscaping & $\$ 8,800$ \\
\hline Sidewalks & $\$ 9,200$ \\
\hline Roofing & $\$ 10,000$ \\
\hline Insulation & $\$ 10,010$ \\
\hline Demolition & $\$ 10,200$ \\
\hline Americans with Disabilities Act High-Capacity Units & $\$ 10,750$ \\
\hline Drywall & $\$ 13,640$ \\
\hline Community/Office Remodel & $\$ 15,000$ \\
Appliances & $\$ 20,836$ \\
Electrical & $\$ 21,230$ \\
\hline Finish Carpentry & $\$ 23,870$ \\
\hline Painting & $\$ 25,650$ \\
\hline Site Amenities & $\$ 28,300$ \\
Windows & $\$ 29,420$ \\
Doors & $\$ 38,258$ \\
\hline Plumbing & $\$ 44,122$ \\
Cabinets & $\$ 49,063$ \\
Flooring & $\$ 51,480.00$ \\
HVAC & $\$ 68,530$ \\
Pavement & $\$ 71,400$ \\
\hline General Requirements & $\$ \mathbf{3 5 , 4 6 4}$ \\
Overhead & $\$ \mathbf{1 1 , 8 1 . 3 4}$ \\
Profit & $\$ \mathbf{3 5 , 4 6 4 . 0 2}$ \\
Total & $\mathbf{6 7 3 , 8 1 6 . 3 6}$ \\
\hline
\end{tabular}




\subsubsection{Guarded Blower Door Tests}

Guarded blower door tests were performed on a subset of representative units to distinguish enclosure leakage to the outside from leakage to adjacent units (Steven Winter Associates 1995). Blower doors were used to depressurize adjacent units to the same pressure as the test unit with respect to the outside so the pressure difference across shared walls was zero (Figure 10). This makes air leakage to adjacent units impossible, so only leakage to the outside is measured. The leakage to the outside accounted for $92 \%$ of the total pre-rehabilitation air leakage and $87 \%$ of the post-rehabilitation air leakage $\left(\frac{\text { unguarded-guarded }}{\text { guarded }} \times 100\right)$. These results are consistent with previous test results in similar low-rise multifamily housing that received air-sealing retrofits (Dentz, Conlin, and Podorson 2012).

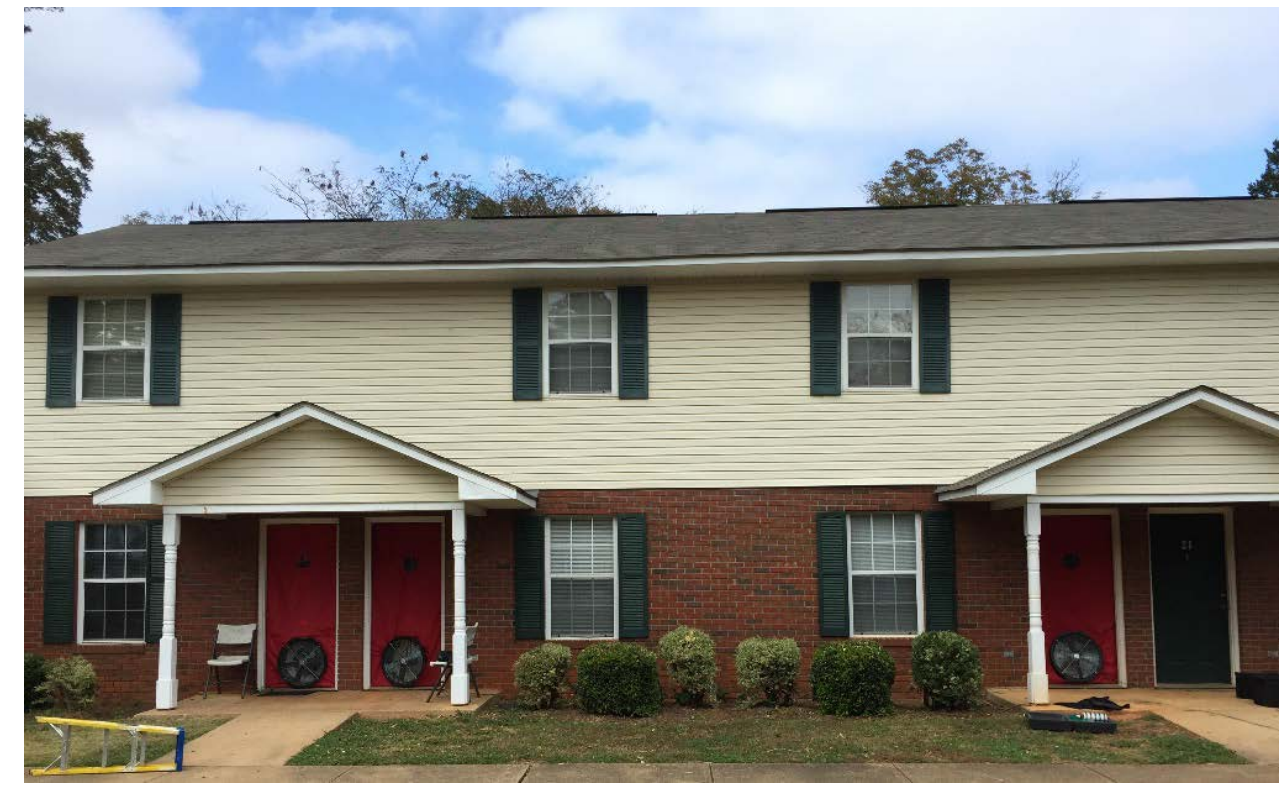

Figure 10. Configuration for guarded blower door test of center unit

\subsubsection{Water Heaters}

The pre-renovation water heaters varied in age, make, model, and condition because some were replaced during the previous 20 years. Every unit in the portfolio received a new Rheem Professional Classic Series 38-gallon electric resistance storage water heater to replace the existing electric resistance storage water heater. Hot water delivery temperatures were measured pre- and post-rehabilitation at the nearest (bathroom) faucet nearly an hour after any potential previous hot water draw could have occurred (occupants vacated their residences during testing, which took approximately an hour per unit). Thirty-eight units were tested pre-rehabilitation and 56 were tested post-rehabilitation (Figure 11). The median pre-rehabilitation temperature was $120^{\circ} \mathrm{F}$, and the median post-renovation set point was $109^{\circ} \mathrm{F}$. The post-rehab group is significantly lower than the pre-rehab group $(\mathrm{p}<0.00001)$. Interestingly, the spread of the second and third quartiles is nearly identical between the two groups, $13^{\circ} \mathrm{F}$ pre-rehab and $14^{\circ} \mathrm{F}$ post-rehab. The total range of measured values was $34^{\circ} \mathrm{F}$ post-rehabilitation, ranging from 98 to $132^{\circ} \mathrm{F}$, compared to the pre-rehab range of $101-140^{\circ} \mathrm{F}$. 


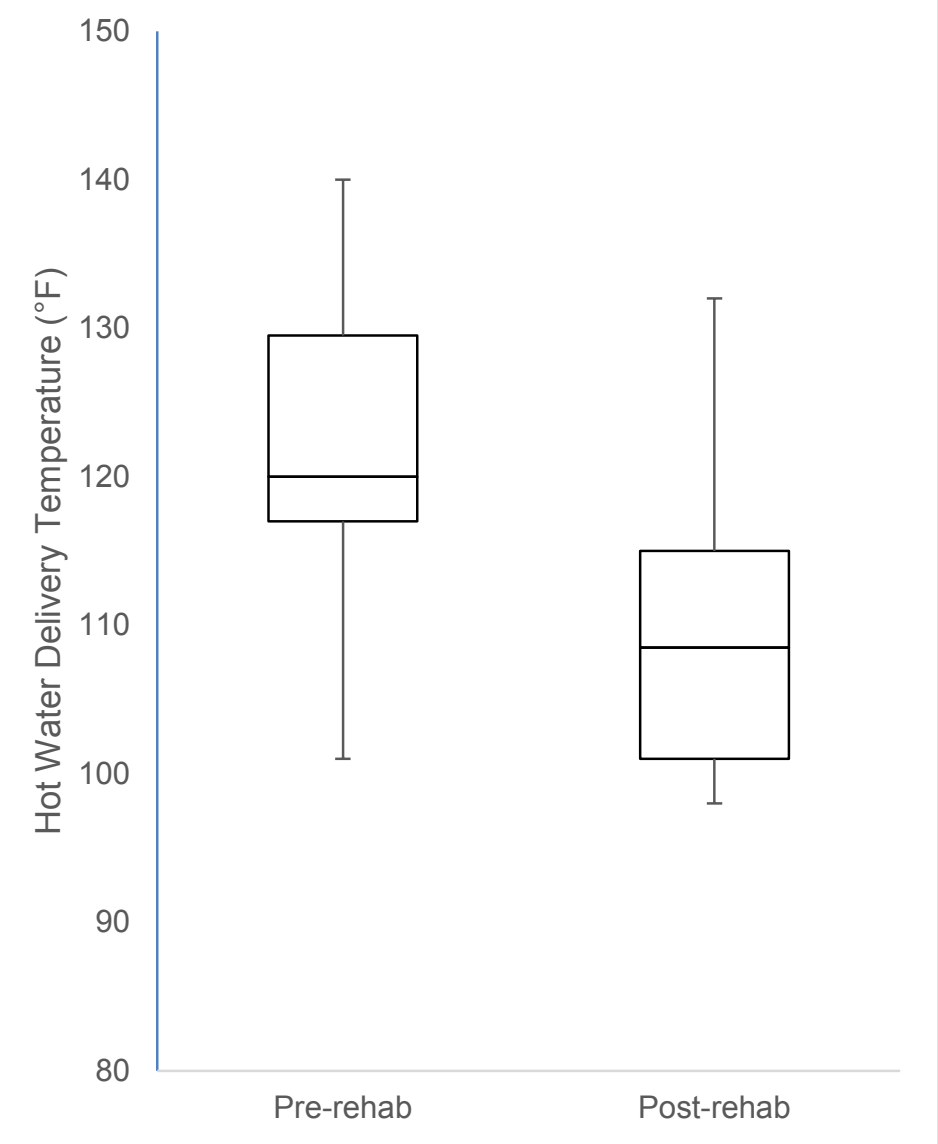

Figure 11. Distribution of water heater delivery temperatures pre- and post-rehabilitation

The variation in temperature in the pre-rehabilitation cohort might be explained by the fact that the residents have access to the water heaters and possibly could have changed the set points over years of use. Or, thermostat performance may degrade over time. However, researchers were surprised by the large range in post-rehabilitation delivery temperatures. Discussions with the plumbers and property managers indicated that the plumbers did not adjust the internal thermostat settings and the tenants were unlikely to make those adjustments. Adjusting the set point requires removing a cover plate and turning a screw with a flathead screwdriver. This indicates that the primary driver for hot water set point temperatures of electric resistance storage water heaters is the default setting from the manufacturer, which appears to be inconsistent. Temperature set point of electric resistance storage water heaters will have a large impact on energy consumption. The U.S. DOE estimates that for every $10^{\circ} \mathrm{F}$ reduction in temperature, a resident may save $3 \%-5 \%$ on their water heating costs ${ }^{9}$. Further, storage water heaters with water temperatures below the median post-rehab water temperature are "ideal" for growth of Legionella pneumophila bacteria according to the Occupational Safety and Health Administration, and many of the senior residents are at high risk of contracting Legionnaires' disease ${ }^{10}$. On the high end, temperatures above $140^{\circ} \mathrm{F}$ can result in scalding. In most cases, it is best to maintain water heater tank temperatures between $122-125^{\circ} \mathrm{F}$.

\footnotetext{
${ }^{9} \mathrm{http} / / /$ energy.gov/energysaver/articles/15-ways-save-your-water-heating-bill

${ }^{10} \mathrm{https}: / /$ www.osha.gov/dts/osta/otm/legionnaires/faq.html
} 


\section{Modeling Results}

\subsection{Building Energy Optimization+ Version 2.3}

BEopt + Version 2.3 (using DOE's EnergyPlus platform) was used to predict the energy and electric utility cost savings from the implemented measure package and additional potential energy-efficiency measures. Models were constructed of the one-bedroom flat, three-bedroom flat, and two-bedroom townhouse unit types. Such unit types are common across the entire Rea Ventures portfolio, although not all are present at each site. The following input variables from Table 5 were adjusted in BEopt to reflect post-rehabilitation upgrades in typical units: windows, lighting, air-source heat pump efficiency, water heater efficiency, water fixture schedule, and attic insulation. Enclosure air leakage remained constant at $13.9 \mathrm{ACH}_{50}$ for the one-bedroom flats, $16.84 \mathrm{ACH}_{50}$ for the three-bedroom flats, and 12.0 $\mathrm{ACH}_{50}$ for the two-story townhouses, all of which were the average pre-rehabilitation values. Models were also simulated at $10 \mathrm{ACH}_{50}$ to investigate the impact of air sealing. Ducts were located in the living zone and modeled as having no leakage to the outside with default calculated values for duct area.

Refrigerator data remained constant $\left(18 \mathrm{ft}^{3} ; 15.9 \mathrm{EF}\right)$, because the pre-renovation conditions varied in age and model, and preliminary research indicated that annual energy consumption of the new models is comparable to that of the pre-rehabilitation models. Kitchen hood and oven/range data also remained constant, because the energy consumption is expected to be identical to the pre-rehabilitation condition. The clothes washer and dryer were modeled as the Building America benchmark. Because those appliances were the tenant's responsibility, they were unlikely to be upgraded during the rehabilitation. The models were simulated using weather data for the Warm Springs location, which is centrally located in the portfolio (Climate Zone 3). This site also contains all three unit types. Site energy consumption results were chosen because the sites are all electric and are displayed in Figure 12 through Figure 14.

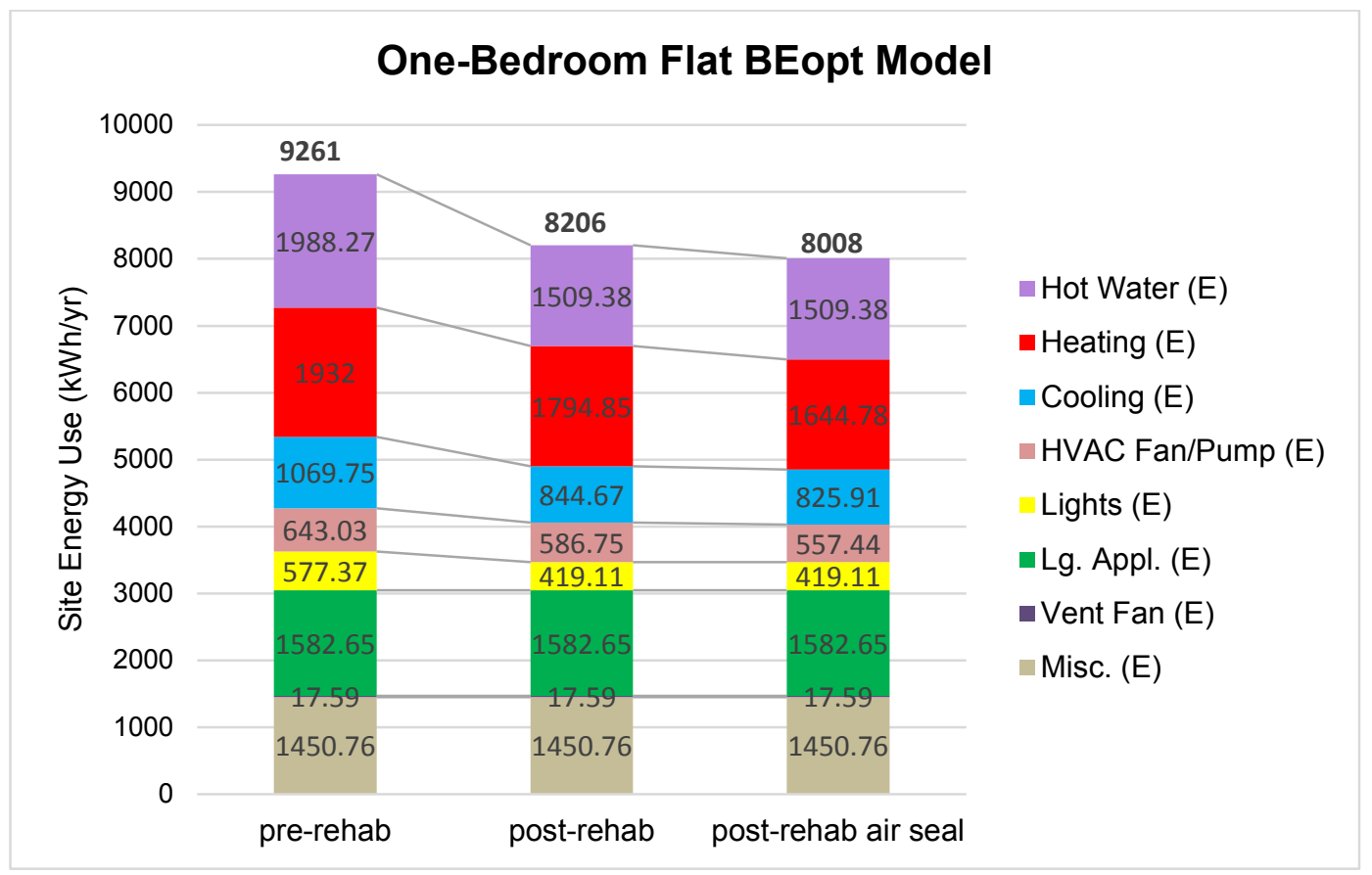

Figure 12. Site energy consumption before and after rehabilitations of typical one-bedroom flat 


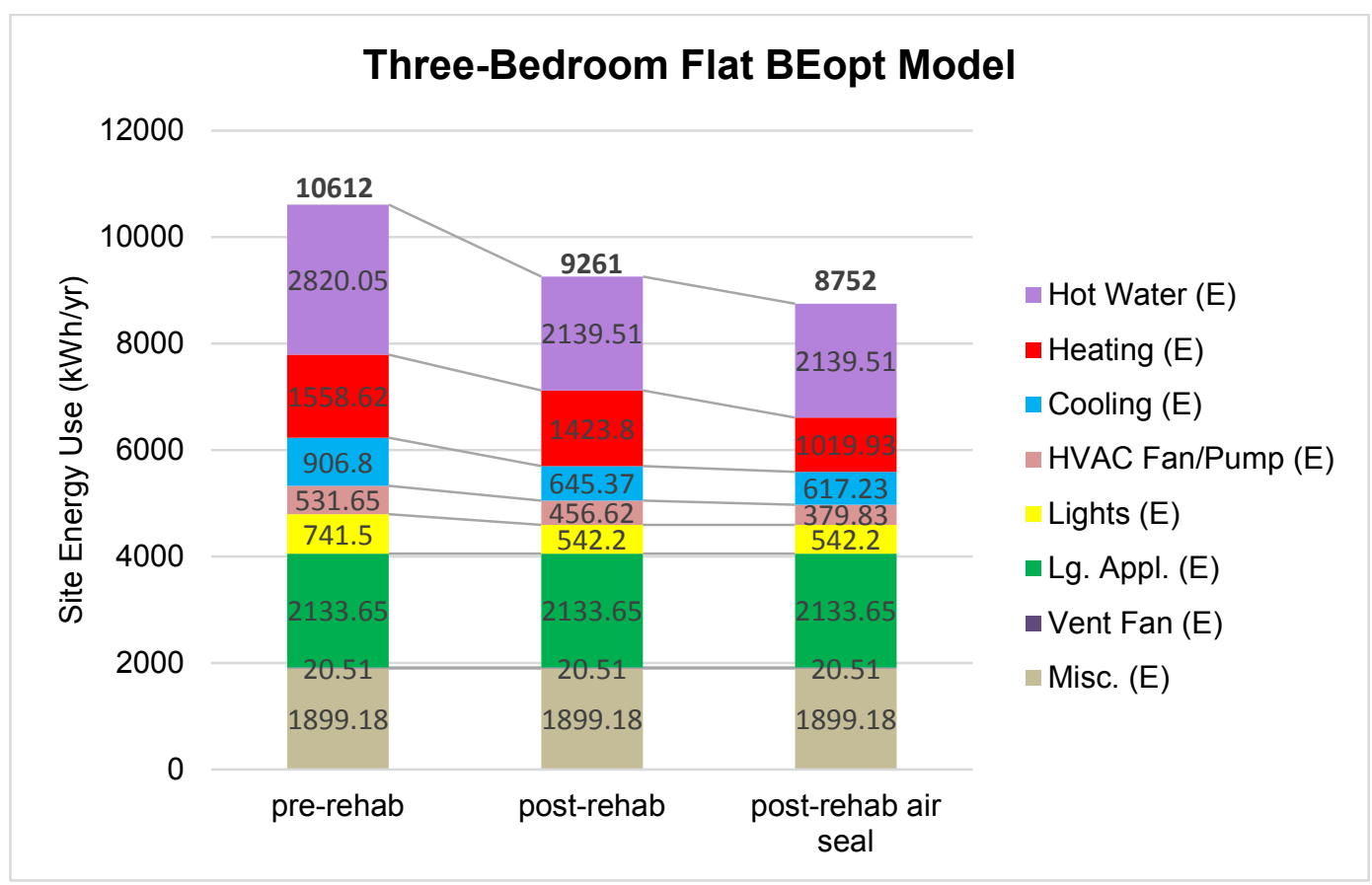

Figure 13. Site energy consumption before and after rehabilitations of typical three-bedroom flat

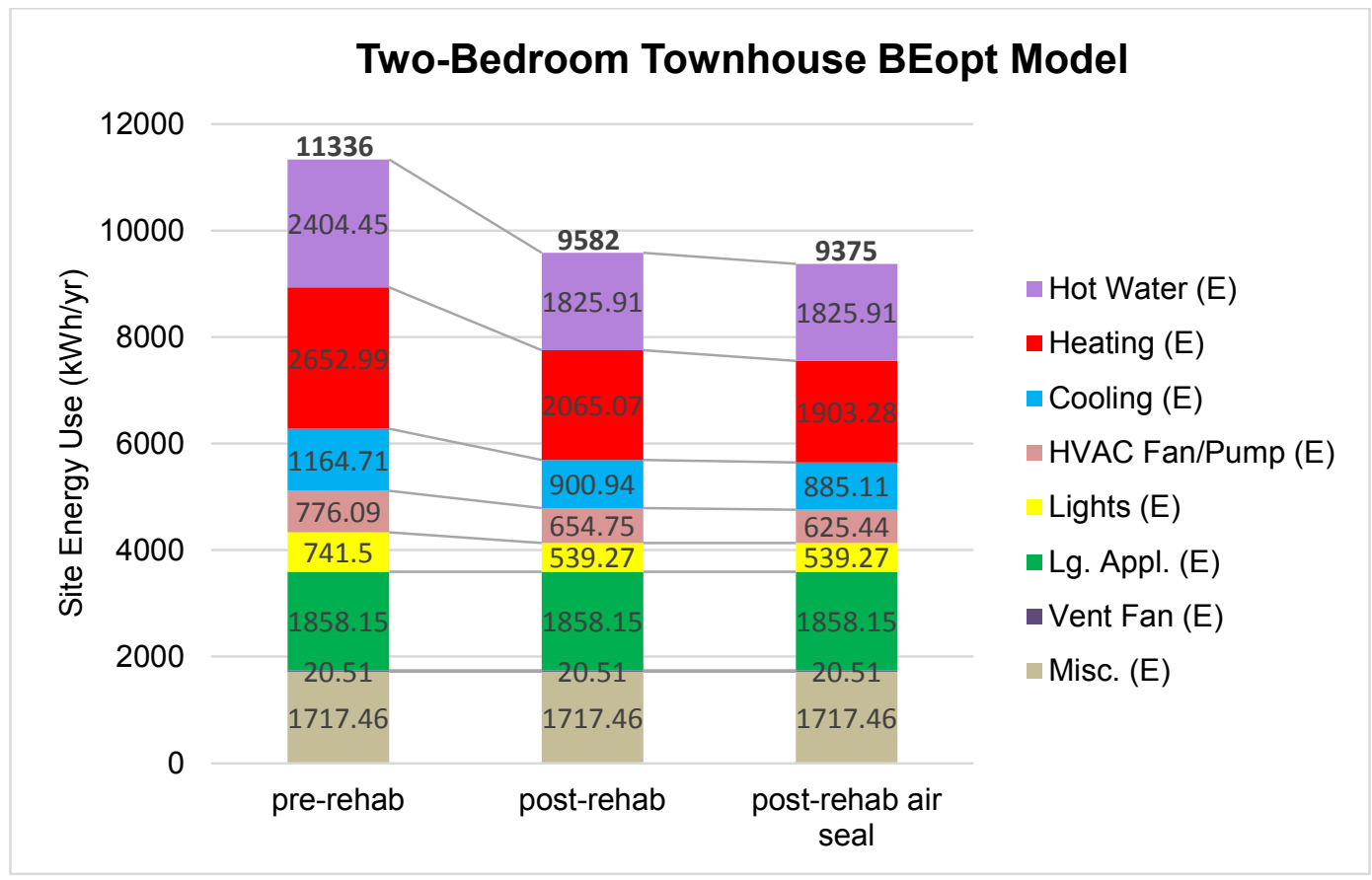

Figure 14. Site energy consumption before and after rehabilitations of typical two-bedroom townhouse 
Total post-rehabilitation site energy savings for the one-bedroom flat, the three-bedroom flat, and two-bedroom townhouse were $11 \%, 13 \%$, and $15 \%$ respectively. If air sealing was performed to a $10 \mathrm{ACH}_{50}$ threshold, the savings would have been $14 \%, 18 \%$, and $17 \%$ respectively compared to the pre-rehabilitation models.

Table 8 contains the site energy component consumptions for the three-bedroom flat and the two-bedroom townhouse. Comprehensive upgrades resulted in $4.4 \%$ cooling and heating savings in the three-bedroom flat and 8.6\% cooling and heating savings in the two-bedroom townhouse; this was accomplished by reducing cooling, heating, and HVAC fan energy. The water heater upgrade, which involved an increase from $0.88 \mathrm{EF}$ to $0.92 \mathrm{EF}$ and a 2-gal reduction in tank capacity, resulted in $6.4 \%$ and $5.1 \%$ reductions in total site energy consumption. Upgrading the linear fluorescent lamps from T-12 to T-8 and replacing all screw-in incandescents with compact fluorescent lamps reduced consumption by $2 \%$ in both unit types.

Table 8. BEopt Modeling Site Energy Consumption Results of the Three-Bedroom Flat and Two-Bedroom Townhouse

\begin{tabular}{|c|c|c|c|c|c|c|}
\hline & \multicolumn{3}{|c|}{ Three-Bedroom Flat } & \multicolumn{3}{|c|}{$\begin{array}{c}\text { Two-Bedroom } \\
\text { Townhouse }\end{array}$} \\
\hline & 音 & 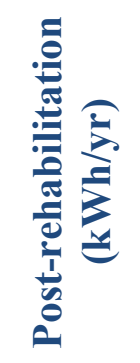 & 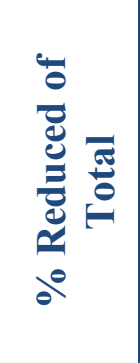 & 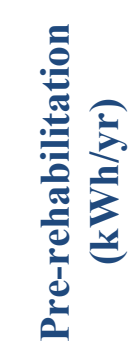 & 兽 & 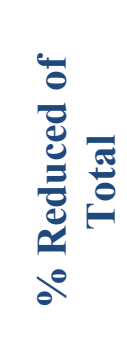 \\
\hline Miscellaneous (E) & 1,899 & 1,899 & $0 \%$ & 1,717 & 1,717 & $0 \%$ \\
\hline Vent Fan (E) & 21 & 21 & $0 \%$ & 21 & 21 & $0 \%$ \\
\hline Large Appliances (E) & 2,134 & 2134 & $0 \%$ & 1,858 & 1,858 & $0 \%$ \\
\hline Lights (E) & 742 & 542 & $1.9 \%$ & 742 & 539 & $1.8 \%$ \\
\hline HVAC Fan/Pump (E) & 532 & 457 & $0.7 \%$ & 776 & 655 & $1.1 \%$ \\
\hline Cooling (E) & 907 & 645 & $2.5 \%$ & 1,165 & 901 & $2.3 \%$ \\
\hline Heating (E) & 1,559 & 1,424 & $1.3 \%$ & 2,653 & 2,065 & $5.2 \%$ \\
\hline Hot Water (E) & 2,820 & 2,140 & $6.4 \%$ & 2,404 & 1,826 & $5.1 \%$ \\
\hline Total & 10,612 & 9,261 & $12.7 \%$ & 11,336 & 9,582 & $15.5 \%$ \\
\hline
\end{tabular}

Southface performed a modeling analysis to determine possible pathways for achieving the developer goal of at least $20 \%$ total energy savings. For the two-bedroom townhouse to achieve $20 \%$ total energy savings, the post-rehabilitation unit will need to reduce site energy consumption to $9,069 \mathrm{kWh} / \mathrm{yr}$ (an additional reduction of $513 \mathrm{kWh} / \mathrm{yr}$ ). Air sealing to $10 \mathrm{ACH}_{50}$ is the most cost-effective additional energy-efficiency measure, estimated to cost $\$ 75$ per unit. However, intentional air sealing was conducted at only one site when the units failed to reach minimum Beacon model savings that are required to qualify for the HEIP rebate. BEopt indicates air sealing to this achievable level will save an additional $207 \mathrm{kWh} / \mathrm{yr}$, which is $306 \mathrm{kWh} / \mathrm{yr}$ shy of the $20 \%$ savings target. Practical additional measures with their associated costs and modeled savings are shown in Table 9. Upgrading to a 15 SEER/8.5 HSPF heat pump is the most cost- 
effective measure to meet the target for the two-bedroom townhouse, but the one-bedroom and three-bedroom flats would need a 16 SEER/8.6 HSPF to meet the target (all 1.5-ton units).

Table 9. BEopt Model Savings of Potential Energy-Efficiency Measures Post-Rehabilitation*

\begin{tabular}{c|c|c}
\hline Measure & Savings (kWh) & Incremental Cost per Unit \\
\hline Air Seal to 10 ACH50 & 207 & $\$ 75$ \\
15 SEER Heat Pump & 345 & $\$ 145$ \\
16 SEER Heat Pump & 931 & $\$ 290$ \\
All Light-Emitting Diodes & 12 & $\$ 138$ \\
21.9 EF Refrigerator & 132 & $\$ 363$ \\
\hline
\end{tabular}

* Incremental cost data from National Residential Efficiency Measures Database, except lighting, which came from chain hardware stores.

Incremental costs for the heat pump upgrades quoted from local contractors and from online sources vary widely and are significantly higher than those found in the National Residential Efficiency Measures Database. ${ }^{11}$

\subsection{Beacon}

Beacon model simulation was performed on each unit that underwent a pre- and postrehabilitation assessment by a certified BPI Building Analyst Professional. The predicted savings at the Warm Springs site were 25\% for the one-bedroom flat, 25.5\% for the three-bedroom flat, and $23.5 \%$ for the two-bedroom townhouse. These savings are shown in Table 10 along with the energy savings by end use.

Table 10. Warm Springs Beacon Model Energy Savings (kWh) Breakdown by End Use

\begin{tabular}{|c|c|c|c|}
\hline & $\begin{array}{c}\text { One-Bedroom } \\
\text { Flat }\end{array}$ & $\begin{array}{c}\text { Three-Bedroom } \\
\text { Flat }\end{array}$ & Townhouse \\
\hline Heating Savings & 796 & 1,143 & 792 \\
Cooling Savings & 622 & 872 & 935 \\
Water Heating Savings & 391 & 817 & 600 \\
Electric Baseload Savings & 820 & 1,139 & 936 \\
HVAC Auxiliary Savings & 20 & 63 & 28 \\
\hline Total Savings & 2,649 & 4033 & 3,291 \\
\hline Post-Rehabilitation Total Use & 7,947 & 11,782 & 10,713 \\
\hline Pre-Rehabilitation Total Use & 10,596 & 15,815 & 14,004 \\
\hline \% Savings & $25 \%$ & $25.5 \%$ & $23.5 \%$ \\
\hline
\end{tabular}

Figure 15 shows predicted electricity costs by month for the three-bedroom flat. Beacon models varied at each site because of slightly different floor plans, duct and envelope leakage conditions, and different pre-rehabilitation appliances. The average Beacon model savings of all units in the entire portfolio across all sites was $29 \%$ for one-bedroom flats, $27 \%$ for three-bedroom flats, and $29 \%$ for two-bedroom townhouses.

\footnotetext{
${ }^{11}$ www.webhvac.com/hvac-prices-lists/heat-pump-price-lists/
} 


\section{Electricity Usage $-\$ 1,881$ or $100 \%$ of cost}

\section{$\$ 300$}

$\$ 250$
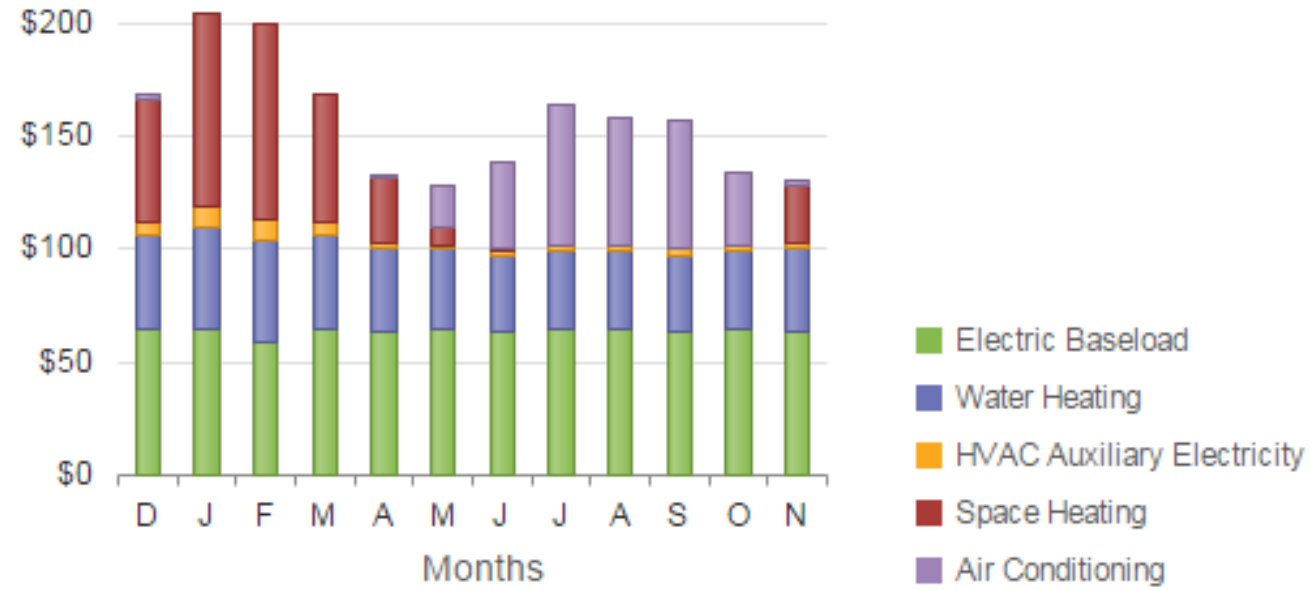

Figure 15. Beacon model electricity costs by month for a three-bedroom flat in Warm Springs

The Georgia Power HEIP uses the predicted site energy savings to determine energy upgrade rebate levels. The savings predicted by Beacon are approximately twice as high as those predicted by BEopt.

\subsection{Home Energy Score}

The DOE Home Energy Score (based on DOE's DOE-2 platform) was explored as a potential tool for analyzing this building type as part of the CNA process and for helping to identify measures to include in an SOW. The same three unit types that were modeled in BEopt and Beacon were scored by an approved assessor in the pre-rehabilitation and post-rehabilitation configurations (Table 11). An experienced assessor needed approximately 15 minutes to score each home when provided with all input data. Actual air leakage rates, which correspond to the $\mathrm{ACH}_{50}$ rates used in BEopt and Beacon, and HVAC system efficiencies were used. These models were performed once the rehabilitation projects were complete as a proof of concept for this software tool and approach. 
Table 11. Warm Springs Home Energy Score Model Results

\begin{tabular}{c|c|c|c}
\hline & $\begin{array}{c}\text { One-Bedroom } \\
\text { Flat }\end{array}$ & $\begin{array}{c}\text { Three-Bedroom } \\
\text { Flat }\end{array}$ & Townhouse \\
\hline Pre-Rehabilitation Score & 10 & 8 & 9 \\
Pre-Rehabilitation Energy & 7,569 & 10,098 & 9,238 \\
(kWh) & 10 & 9 & 10 \\
Post-Rehabilitation Score & 6,672 & 9,048 & 8,296 \\
Post-Rehabilitation Energy & 897 & 1,050 & 942 \\
(kWh) & $11.9 \%$ & $10.4 \%$ & $10.2 \%$ \\
\hline
\end{tabular}

The Home Energy Score software recommended the following energy-efficiency measures for each unit type:

- One-bedroom flat: Replace later-ENERGY STAR heat pump water heater

- Three-bedroom flat: Replace later-ENERGY STAR heat pump and ENERGY STAR heat pump water heater

- Townhouse: Replace later-ENERGY STAR heat pump and ENERGY STAR heat pump water heater.

Rea Ventures did upgrade the units with heat pumps that meet the ENERGY STAR 8.2 HSPF and 14.5 SEER minimum efficiency standards. Because of the utility closet configuration, only a lowboy or tankless water heater can fit in the unit; the electric tank water heater was chosen over the electric tankless version because upgrading the electrical wiring to provide sufficient power to tankless heaters would incur substantial costs.

\subsubsection{Modeling Software Comparison}

Southface obtained the pre-rehabilitation average monthly electricity bill for each unit at Warm Springs. From that, actual annual electricity costs for each unit type were computed. The average residential electricity rate for Georgia used by BEopt was $\$ 0.1054 / \mathrm{kWh}$. This rate was used to convert annual modeled total energy consumptions to electricity costs for BEopt, Beacon, and Home Energy Score results, which were then compared to the actual costs (Table 12). BEopt results were significantly closer to actual utility data; Beacon results indicated significantly higher pre-rehabilitation energy consumption in the three-bedroom flat and two-bedroom townhouse compared to actual results. Home Energy Score results were consistently lower than actual costs (Roberts et al. 2012). 
Table 12. Comparison of Pre-Rehab Actual to Modeled Annual Electricity Costs

\begin{tabular}{c|c|c|c|c|c|c|c}
\hline & Actual & BEopt & $\begin{array}{c}\% \\
\text { Difference }\end{array}$ & Beacon & $\begin{array}{c}\% \\
\text { Difference }\end{array}$ & $\begin{array}{c}\text { Home } \\
\text { Energy } \\
\text { Score }\end{array}$ & $\begin{array}{c}\% \\
\text { Difference }\end{array}$ \\
\hline $\begin{array}{c}\text { One- } \\
\text { Bedroom } \\
\text { Flat }\end{array}$ & $\$ 1,188$ & $\$ 1,111$ & $-6 \%$ & $\$ 1,117$ & $6 \%$ & $\$ 798$ & $-33 \%$ \\
$\begin{array}{c}\text { Three- } \\
\text { Bedroom } \\
\text { Flat }\end{array}$ & $\$ 1,278$ & $\$ 1,273$ & $0 \%$ & $\$ 1,667$ & $30 \%$ & $\$ 1,064$ & $-17 \%$ \\
$\begin{array}{c}\text { Two- } \\
\text { Bedroom } \\
\text { Townhouse }\end{array}$ & $\$ 1,277$ & $\$ 1,360$ & $7 \%$ & $\$ 1,476$ & $16 \%$ & $\$ 974$ & $-24 \%$ \\
\hline
\end{tabular}




\section{Process Gap Analysis}

\subsection{Capital Needs Assessment eTool}

As part of an effort begun in 2009 to align federal rental housing policies and procedures, HUD and the USDA Rural Development Administration developed an automated process for preparing, submitting, and reviewing CNAs. The software tools and Web applications that form the elements of this automated process are called the CNA eTool. The HUD Federal Housing Administration has drafted a Multifamily Accelerated Processing Guide, which contains technical corrections, policy integration, and proposed policy revisions. At the time of this writing, the documents and tools were still under review. ${ }^{12}$

This new process will incorporate requirements and incentives for energy-efficiency upgrades into the process and reward structures for rehabilitation and new construction projects. Although the procedures and tools identified in the Multifamily Accelerated Processing Draft Guide may be appropriate for mid- and high-rise multifamily buildings, they do not include appropriate pathways of compliance for low-rise buildings that dominate the market in the Southeast.

\subsubsection{ASHRAE Level II Energy Audit}

All buildings older than 10 years that are not ENERGY STAR certified must complete an ASHRAE Level II energy audit as a component of their 10-year CNA process. The audit is used to analyze utility consumption and cost benefits, and it informs all utility consumption elements of the CNA. As with this project, the CNA is critical for developing SOWs for rehabilitation projects.

Approved credentials for professionals include those from American Energy Engineers Association (Certified Energy Manager or Certified Energy Auditor); ASHRAE (High Performance Building Design Professional); BPI (Multifamily Building Analyst); or Residential Energy Services Network (Home Energy Rating System Rater). To expand the pool of professionals to include those qualified to perform audits on low-rise multifamily buildings with individual systems, the authors recommend the following additions and corrections:

- Replace ASHRAE High Performance Building Design Professional with ASHRAE Building Energy Assessment Professional

- Add BPI Building Analyst Professional

- Add DOE Home Energy Professional Energy Auditor.

\subsubsection{Utility Consumption Baselines, Benchmarking, and Energy Scoring}

The Multifamily Accelerated Processing Guidelines require that the CNA include utility bill benchmarking using ENERGY STAR Portfolio Manager ${ }^{13}$ during underwriting at least every 10 years. For substantial rehabilitation projects, this benchmarking must include the generation of an ENERGY STAR score. However, scores are available only for multifamily buildings with 20 or more units and a minimum of 12 consecutive months of utility data for each unit. None of the buildings in the Rea Ventures portfolio are eligible for an ENERGY STAR score.

\footnotetext{
${ }^{12} \mathrm{http} / /$ portal.hud.gov/hudportal/HUD?src=/program_offices/housing/mfh/map/maphome

${ }^{13}$ www.energystar.gov/buildings/facility-owners-and-managers/existing-buildings/use-portfolio-manager
} 
The score is used as a trigger for requirements and incentives. For instance, for buildings with a score lower than 60, the developer must identify cost-beneficial energy-efficiency measures as mandatory components of the rehabilitation project. Cost beneficial is defined as a return on investment that is shorter than the life of the product. Also, for properties achieving ENERGY STAR certification (scoring 75 or greater) the developer may use reduced utility cost estimates in the operating expense forecasts. This approach may allow developers to charge higher rents and keep the total monthly expenses for renters constant by reducing the utility allowance.

Because smaller buildings are not eligible for this score, alternative pathways for demonstrating superior energy performance should be explored. One option would be to use an asset rating rather than an operational rating of building performance. The Home Energy Rating System Index score ${ }^{14}$ is widely accepted, available, and used to certify low-rise multifamily new construction buildings as ENERGY STAR ${ }^{15}$. The Home Energy Rating System Index provides a measure of predicted performance relative to the Home Energy Rating System Reference Home (based on the 2006 International Energy Conservation Code). The DOE Home Energy Score ${ }^{16}$ is appropriate for existing row house and townhouse buildings, but not for stacked configurations. The Home Energy Score provides a true measure (not normalized) of performance relative to comparable homes.

The three common unit configurations were scored under pre- and post-rehabilitation conditions (Table 11). The pre-rehabilitation units scored 8-10 out of 10 and the post-rehabilitation units scored 9-10. The Home Energy Score may be under-predicting energy use in this building type, but its ease of use compared to other energy modeling applications makes it attractive for further exploration in this application.

HUD Notice H-2015-04: Methodology for Completing a Multifamily Housing Utility Analysis was released June 22, 2015 and should be used for calculating utility allowances. The methodology permits sampling of units by unit size (number of bedrooms). For buildings or sites with 1-20 of the same unit size, no sampling is permitted. Most, if not all, of the Rea Ventures sites would not be eligible for sampling, despite the fact that they were built and have been maintained and rehabbed consistently. Sampling, as was done in this case, leads to considerable cost savings.

\subsubsection{Total Cost of Ownership}

The new eTool spreadsheet has requirements for calculating the total cost of ownership of existing energy- and water-consuming equipment and for recommended upgrades and replacements. These requirements apply to in-unit and common area equipment for tenant- and owner-paid utilities.

\footnotetext{
${ }^{14}$ www.resnet.us/hers-index?

$15 \mathrm{https}: / /$ www.energystar.gov/index.cfm?c=new_homes.hm_index

${ }^{16}$ http://energy.gov/eere/buildings/home-energy-score
} 


\section{Conclusions}

Rea Ventures rehabilitated 14 properties containing 418 units. This effort was funded by the USDA Rural Development program, private investments, and utility energy-efficiency incentives. Original SOWs were developed based on a federally prescribed process using a thirdparty CNA that did not include energy efficiency in making upgrade decisions. Partnering with Southface to develop a prescriptive energy-efficiency upgrade package for its Georgia portfolio, Rea Ventures was able to achieve an average of $15 \%$ reduction in resident energy costs. This was achieved by using a rehabilitation approach that allows the occupants to remain at home during the work. Rea Ventures was also able to recover more than $\$ 300,000$ from Georgia Power in incentives by participating in the state's Home Energy Improvement Program. Most of the savings came from upgrades to HVAC, lighting, and water heaters.

Some opportunities for energy and comfort savings were unrealized - specifically, air- and ductsealing measures were not performed and higher-efficiency heat pumps were not installed. By air sealing the attic plane before adding insulation and air sealing the interior penetrations, contractors could have reduced enclosure air leakage. Similarly, sealing duct boots to the drywall would have reduced total duct leakage. However, none of these measures were identified in the CNA that was used to develop the USDA-funded SOW. Furthermore, the developer was able to obtain utility rebates in other ways.

The following data should be collected during a CNA to quantify current and future building energy metrics and develop a thorough SOW:

- Airtightness (collected by visual or measured means)

- HVAC efficiency

- Duct location and sealing (collected by visual or measured means)

- Water heater efficiency

- Window type, size, and orientation

- Attic, wall, and foundation insulation levels

- Combustion appliance safety conditions.

For low-rise multifamily buildings, any of the following would be qualified to assess the building for necessary energy-efficiency upgrades: a BPI Building Analyst Professional, DOE Home Energy Professional Energy Auditor, Home Energy Rating System Rater, or Home Energy Score assessor. Certified professionals from BPI and the Residential Energy Services Network are qualified to assess combustion safety risks.

The building developers did express that they are able to recoup part of their investment in energy efficiency through the tax credit syndication process. When an entity such as Rea Ventures receives a Low Income Housing, New Markets, Historic, or Renewable Energy Tax Credit, it then sells that tax credit to investors to offset the investor's own federal tax liabilities. Through its experience in this market, Rea Ventures has found that it can command a premium for its tax credits because the marketplace perceives that energy-efficient and green-certified buildings are of superior quality and provide a more secure investment vehicle. Rea Ventures has 
also found that installing newer efficient technologies garners a positive perception from potential lessees years after the property loses its "being new" marketability.

Developing SOWs from the current CNA process limits the ability to deliver energy-efficiency improvements for LIHTC and USDA Rural Development rehabilitation projects, because building and equipment energy efficiency is not specifically analyzed in the rehab or life cycle financial calculations. A split incentive between property owners and residents rewards residents with lower utility bills but does not necessarily reward owners with higher rents when highperformance measures are implemented. The Multifamily Accelerated Processing Guide and eTool attempt to rectify these situations by rewarding projects with favorable underwriting terms and giving owners the ability to raise rents commensurate with lower utility bills. However, that process is designed for larger-scale buildings and is not accessible to smaller buildings that dominate the market in the Southeast.

Researchers were surprised at the large variation in measured hot water delivery temperatures, and the low median post-rehabilitation of $109^{\circ} \mathrm{F}$. These differences could indicate variability in water heater set points from the manufacturer or variability in the precision of the water heater thermostats. The water heater set point has a significant impact on total hot water energy consumption, as well as having consequences for resident health and safety, so this area deserves further investigation. Additionally, voluntary programs may consider requiring verification of water heater deliver temperature as both an energy efficiency measure and a health and safety measure. 


\section{References}

Dentz, J., F. Conlin, and D. Podorson. 2012. Case Study of Envelope Sealing in Existing Multiunit Structures, (October).

Fuhry, L., J. DeCoursey, and W. Wells. 2013. 2013 QAP ANALYSIS Green Building Criteria in Low-Income Housing Tax Credit Programs.

Roberts, D., N. Merket, B. Polly, M. Heaney, S. Casey, and J. Robertson. 2012. Assessment of the U.S. Department of Energy's Home Energy Scoring Tool.

Steven Winter Associates. 1995. Simplified Multizone Blower Door Techniques for Multifamily Buildings. Norwalk, CT.

U.S. Housing and Urban Development. 2013. HUD's National Low Income Housing Tax Credit Database: Projects Placed in Service through 2013. 
